\title{
Research on the Protection and Reuse of Industrial Heritage from the Perspective of Public Participation-A Case Study of Northern Mining Area of Pingdingshan, China
}

\author{
Xiaolu Wu ${ }^{1}$, Li Yu ${ }^{2}$, Haosen Fang ${ }^{3}$ and Jing $\mathrm{Wu}^{1, *}$ \\ 1 School of Urban Design, Wuhan University, Wuhan 430072, China; Xiaolu_W@hotmail.com \\ 2 School of Geography and Planning, Cardiff University, Cardiff CF10 3AT, UK; yul@cardiff.ac.uk \\ 3 Hubei Urban Planning and Design Institute Co., Ltd., Wuhan 430064, China; cgy_office@zonaland.cn \\ * Correspondence: Jing.wu@whu.edu.cn; Tel.: +86-1777-1876-667
}

Citation: Wu, X.; Yu, L.; Fang, H.; $\mathrm{Wu}, \mathrm{J}$. Research on the Protection and Reuse of Industrial Heritage from the Perspective of Public ParticipationA Case Study of Northern Mining Area of Pingdingshan, China. Land 2022, 11, 16. https://doi.org/ 10.3390/land11010016

Academic Editors: Nikos A. Salingaros, Alexandros A. Lavdas, Michael W. Mehaffy and

Ann Sussman

Received: 17 November 2021

Accepted: 17 December 2021

Published: 22 December 2021

Publisher's Note: MDPI stays neutral with regard to jurisdictional claims in published maps and institutional affiliations.

Copyright: () 2021 by the authors. Licensee MDPI, Basel, Switzerland. This article is an open access article distributed under the terms and conditions of the Creative Commons Attribution (CC BY) license (https:// creativecommons.org/licenses/by/ $4.0 /)$.

\begin{abstract}
With the decline of the big industrial period, many industrial cities in China are facing the problem of urban transformation. Post-industrial economic activities and social life often replace the demand for land and population growth, and the particular type of cultural heritage of industrial heritage is often abandoned and decayed. Recent domestic and foreign research has responded to this problem and sought to provide solutions for the protection and reuse of industrial heritage. Despite some progress, the advice and feelings of ordinary citizens are often rarely considered, or how local urban characteristics become the core of urban reconstruction. To solve this problem, the focus of this study is the case study of Pingdingshan City. Pingdingshan is an industrial city with coal as its core industry. Shortly, the problem of industrial heritage will be a severe problem facing the city. The study included research designs and methods for collecting data from field observations, questionnaires, interviews, and literature studies. In the process, researchers have critically considered the importance and implications of public participation in exploring the way in which they are protected and reused through the protection and reuse of industrial heritage. It is particularly worth mentioning that in the reconstruction of the protection and reuse of industrial heritage in Pingdingshan, government officials and enterprises lack sensitivity to local conditions and the views of residents. The study concluded that the protection and reuse of industrial heritage require public participation and that the public's demands can guide and determine the way industrial heritage is protected and reused.
\end{abstract}

Keywords: industrial heritage; public participation; protection and reuse

\section{Introduction \\ 1.1. Protection and Reuse of Industrial Heritage}

With the rapid development of Chinese society, urban industry is facing the transformation of its industrial structure, ecological and environmental balance, and sustainable economic development. Components of the of industrial system are facing obsolescence, and the concept of "industrial heritage" has emerged [1]. Industrial heritage is a particular type of cultural heritage. Increasing numbers of people have realised that the closed factories, depleted mines and abandoned railways have lost their original production functions, but those that carry industrial civilisation have, over time, accumulated an industrial heritage with a specific value. Industrial heritage is a testimony to human civilisation and historical development. Its historical and cultural values, knowledge value, scientific and technological value, economic value, and artistic value have been widely recognized worldwide [2]. Industrial heritage is defined in the Nizhny Tagil Charter for the Industrial Heritage (2003), published by the International Committee for the Conservation of the Industrial Heritage (TICCIH). In order to protect and reuse industrial heritage, this concept is defined by TICCIH in the "Nizhny Tagil Charter" (2003) [3] as consisting of industrial cultural heritage sites which have historical, technical, social, architectural or scientific value. 
These remains consist of buildings, structures and machinery, workshops, factories, mines, warehouses and storage rooms, energy production, transmission, use and transportation, and all underground structures and locations. Social activities associated with the industry (such as houses, religious pilgrimage sites, educational institutions) are also included in the scope of industrial heritage. The charter clearly defines the importance of buildings and structures built for industrial activities, artefacts and their towns and landscapes, as well as all other tangible and intangible forms of expression. As technology changes, sites that continue to be used in specific industries often experience significant physical changes. Therefore, Clark also stated that the remains of industrial heritage are not just buildings of industrial activity: they include five landscapes and areas, mechanical and industrial archaeology, relics and traces of other processes, and production [4]. According to the Spanish National Industrial Heritage Program, the definition of industrial heritage is the collection and management of movable and immovable assets produced through mining, transformation, transportation, distribution and other activities, as well as social systems related to working-class culture, and management. This is the industrial revolution-the result of the established economic system [5].

The protection and reuse of industrial heritage is an important method of sustainable development under urban renewal. The urban renewal process is now increasingly incorporating heritage protection factors into the overall urban renewal plan. Heritage protection refers to the process of caring for a place to maintain its heritage and cultural heritage value [6]. Some scholars also say that the protection of the historical environment needs to maintain a balance between retaining the intrinsic value of the past and meeting new demands $[7,8]$. According to relevant research, industrial heritage attention has particular meanings and values, which are cultural value, historical value, technological value, aesthetic value, economic value, educational value, social value. Regarding cultural value, planning professionals state that the maintenance of urban layout is one of the most important characteristics of urban cultural identity and that the industrial landscape is an important part of this [9]. People realize the "cultural value" of this industrial heritage and the appreciation of its unique landscape has penetrated into public psychology [10]. Heritage conservation can help to develop specific regional characteristics of urban areas [11]. Laurian and Shaw state that the architectural and cultural landscape leftover from the old industrial era shape a sense of belonging, social traditions and historical and cultural identity spanning centuries [12]. According to Moore and Whelan, the basic concept behind the protection of industrial heritage is that those landmarks are not only historical but also narrative, and they are related to memory, which is larger than or equal to history [13]. Therefore, the industrial heritage has historical value. Unlike other types of cultural and natural heritage, industrial heritage has been mainly precipitated in the period after the emergence of modern science and the industrial revolution. Many examples of industrial heritage contain innovative scientific and technological inventions and creations, among which the study of natural laws, the production and organization of science, etc., will inspire the future generations of science and technology [14]. Industrial heritage can be defined as a form of "aesthetics of deindustrialization" and "aesthetics of scenery in decline" [15]. Researchers such as Xing also show that the structural logic and precision in the structure of these industrial heritages are direct expressions of modernist architectural aesthetics and machine aesthetics, and have important aesthetic value. The Zollverein Coal Mine Industrial Park is located in Essen, Western Germany. It was once the world's largest, most efficient and most technologically advanced coal mining base. Due to its simple appearance and practical "Bauhaus" style, it is regarded as the most modern and beautiful coal mine building in the world at that time [16]. Del Pozo and González state that, in Spain, it has been emphasised that industrial heritage should be the main tool for economic recovery, with it being a potential resource to help find solutions. Therefore, industrial heritage will maintain its territorial value as an economic resource [17]. From the perspective of geographical location and land value, the preservation of historical industrial buildings in good condition can enable the infrastructure of the old districts to continue to 
work and contribute to the tourism industry with a focus on industrial sites. It is also one of the fastest growing economic sectors in Europe [16]. Industrial heritage is an irreplaceable source for history and engineering education. Many industrial sites in Europe and the United States have been used as teaching bases to combine industrial heritage protection, propaganda, and education [18]. For example, the sightseeing tower 8 converted from the steelmaking blast furnace in the Duisburg Landscape Park in Germany is a science education platform where visitors can intuitively learn steelmaking knowledge [16]. Industrial heritage has social value because it is often locally symbolic, helping to promote residents' pride and cohesion. Heritage sites are also common means and venues for linking people to their roots. This helps to develop and enrich individual cultural identity as a coherent group of different locations, history, aesthetics, religious beliefs, etc. [19]. British Heritage (2005) also expresses that heritage protection can enrich people's understanding of the community while helping to create a unique sense of place and community. As a result, people's sense of community and belonging can be strengthened.

The theories and case studies of many researchers show that the protection and reuse of industrial heritage are basically carried out based on the tourism industry, mainly in the form of building a museum on the original site [20-22], transforming the original site into a landscape park to provide public recreation space for the public $[5,14,16]$, comprehensive development combined with shopping tourism $[5,21]$, and site-based "processing attractions" of a heritage nature [21].

Cai explains that although China's industrial heritage protection started relatively late, in recent years, it has gradually formed a unique exploration path in line with China's national conditions [23]. At present, the relevant state departments attach great importance to the protection of industrial heritage. Since 2010, the China Science and Technology Coordination Research and Propaganda Department has commissioned the China Urban Planning Association to conduct industrial heritage research for three consecutive years, and has investigated and evaluated the industrial heritage of 12 cities and formed a series of research results. To date, the China Association for Science and Technology (CAST) has published the first 100 industrial heritage protection lists [24]. On the other hand, in China's planning and policy-making, the current public participation is inadequate, and the government cannot meet the increasing public participation requirements of the general public [25]. Chinese scholars have found that there are two forms of public participation in China: one is public participation in initiatives proposed and led by the government, and the other involves questions raised by the public. However, most of these questions have not received government responses, and there is no effective public participation, but only some civil litigation or recommendations $[23,25,26]$. Public participation in China involves only the emergence of some phenomena, and there is no effective participation system. Public participation faces serious difficulties and obstacles; its development is very uneven and the results are not ideal [27]. It can only be said that the meaning of public participation represents a kind of demand and hope. For a city that is prosperous because of its coal mines, the remnants of the urban industrial period have a very high protection and reuse value for the city. Pingdingshan's coal mining industry is not only closely integrated with its local history, humanities, and economy, but is also one of the first mining cities established after the founding of the People's Republic of China (PRC) [28].

\subsection{Public Participation in Project Evaluation}

Many experts and scholars apply different ways and methods to public participation in heritage project research, especially in the context of urban renewal and protection and reuse of industrial heritage. Landorf conducted a content analysis of the management plan for six industrial world heritage sites in the UK [29]. Landorf used a simplified coding instrument by Ruhanen for evaluation. The analysis focuses on the degree to which each plan integrates the four key sustainability dimensions. Finally, Landorf builds an evaluation framework through coding dimensions and McCann's social problem-solving process, which is used to discuss the weight, breadth, depth, fairness, and long-term 
changes of stakeholder participation in establishing a collective vision for the future of the problem domain. Spennemann mentioned in another study that Peter Savage conducted a heritage assessment in the Shire of Esk, southwest of Brisbane, in 2000 [30]. Savage uses two methods for evaluating heritage research, expert-driven and community workshopbased heritage research and open-ended anonymous questionnaires. By comparing the results obtained by the two methods, Savage concluded that the survey method more accurately reflects the heritage of a community. Spennemann believes that such surveys provide more choices of locations that are important to the community, thereby enabling more comprehensive decision-making. In two case studies in Shanghai, Zhong and Leung used a mixed methods approach to study how governance-based community participation can become a sustainable way for heritage community renewal [31]. Through qualitative interviews and non-participatory observations, how different agents can be authorized and influence community participation can be explored. By observing community meetings and other informal discussions, it is possible to understand the process of the project from discussion and negotiation to decision-making. The interviewees who participated in the project included community residents, ten local officials, professionals and NGO leaders.

Today, a number of scholars have studied public participation. There are three main forms of community involvement, namely mandatory participation, induced participation, and spontaneous participation [32-35]. Mandatory community participation refers to the minimum level of participation of residents who lack the right to self-determination. Induction or middle-level community participation provides local residents with a voice in heritage management and tourism development. However, they have no actual power or control over the decision-making process, and their input is neither sought nor heard $[34,35]$. Zhang and colleagues also state that power holders ultimately decide whether to accept or reject residents' opinions in the planning and development process [36]. The highest level of participation is a form of self-styled participation, in which residents have the right to decide and control the development planning process [37].

The SenStadtUm model consists of four levels, in ascending order, from weakest to strongest: (1) information, (2) collaboration, (3) joint decision-making, and (4) decisionmaking (Figure 1). The increase in the degree of influence is accompanied by an increase in the length of the participation process. At level 1, stakeholders receive information about planned projects from official decision-makers only through announcements or public meetings. At level 2, interested parties are also invited to comment on the project and its implementation, but they have no role in decision-making. The latter is only available at level 3, at which they can jointly determine the project's wishes and goals, as well as its implementation. The highest level of impact is reached at level 4 [38].

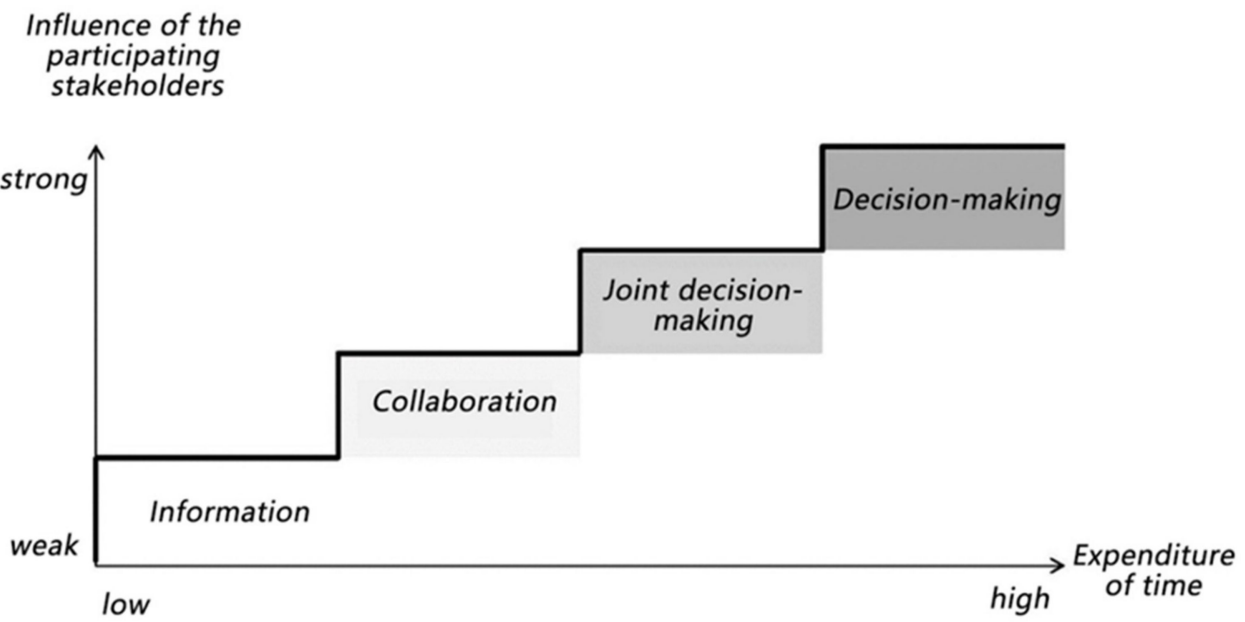

Figure 1. Multi-level model of participation. 


\subsection{Study Area}

The research area is the southern mining area of Pingdingshan. It is a prefecturelevel city under the jurisdiction of Henan Province and is primarily a coal industrial city. Pingdingshan City is located in the central part of China's national economic development from east to west. It is the largest industrial base in southern Henan. Before the founding of the PRC, Pingdingshan was not a city. Because of the development and construction needs after the founding of the PRC, the country developed the Pingdingshan coalfield on a large scale, and later established the preparatory office of the Pingdingshan Coal Mine in 1954. In order to better serve the mining and production of this area, Pingdingshan was provided with supporting facilities such as hospitals, schools and residential areas. In this way, the living areas that formed around the mining region were connected into one large area, which eventually developed to the size of a city. On 26 March 1957, with the approval of the State Council, Pingdingshan City was established, which is one of the 11 coal cities in the country. Pingdingshan City is rich in underground resources and 57 kinds of minerals have been identified. The total reserves of raw coal comprise 10.3 billion tons, known as the Zhongyuan Coal Bunker. The Northern mining area is located north of the main urban area, and is the largest coal mine in Pingdingshan City, with the most concentrated areas of coal resource distribution, covering a total area of about 65 square kilometres [28]. The Northern mining area stretches for dozens of kilometres, involving as many as 12 management units (Figure 2).

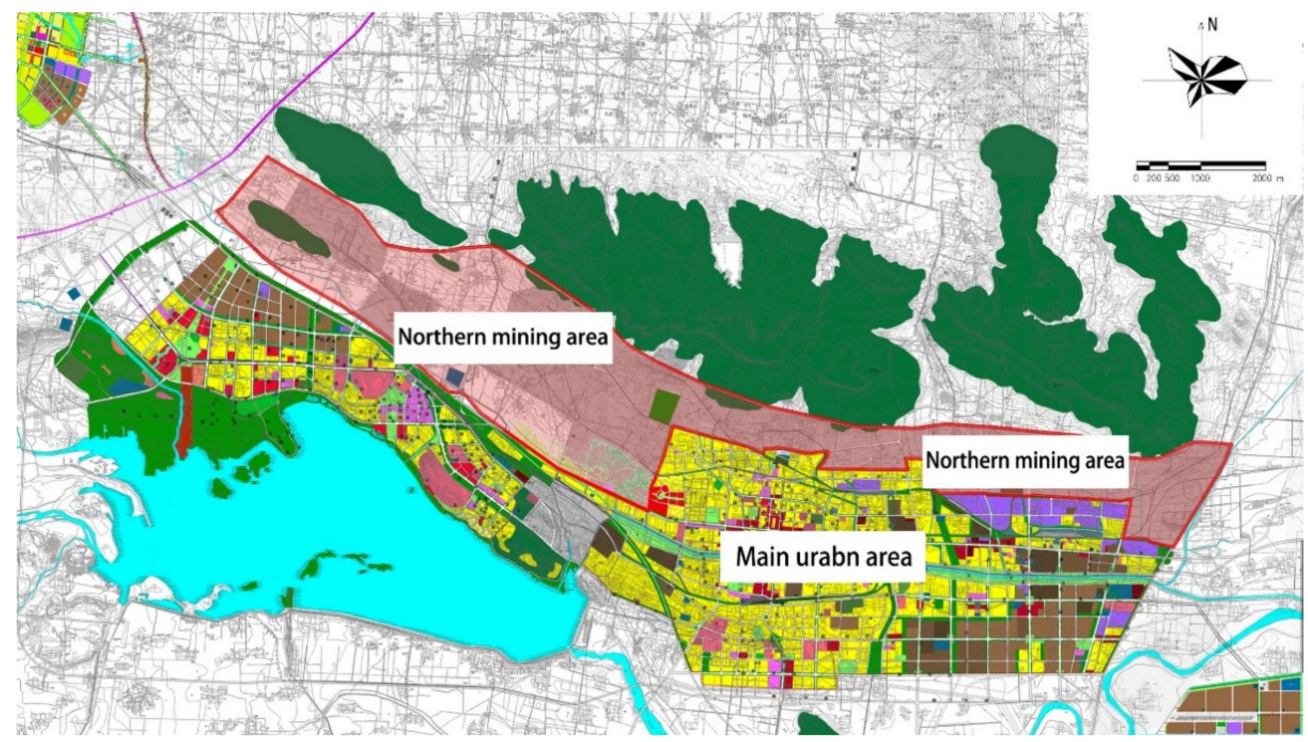

Figure 2. Location planning map of the Northern mining area of Pingdingshan.

In the 1950s and early 1970s, Pingdingshan was basically a mine city. Coal, as its main industry, accounted for more than $90 \%$ of its GDP. Subsequently, from the early 1970s to the early 1990s, Pingdingshan City established an economic model combining the development of three industries: agricultural production, industrial production, and tertiary industry. The proportion of the secondary industry has risen rapidly, and the overall situation was 2:1:3. Later, in the early 1990s, the industrial structure of Pingdingshan was adjusted to 2:3:1 [39].

The period from 2001 to 2008 was the period of the fastest economic growth in Pingdingshan. The production factors were attracted to the secondary industry dominated by coal mining. The industrial structure of the city showed a rise in the secondary industry and a decline in the tertiary industry. The economic growth of Pingdingshan became increasingly dependent on energy, and the proportion of the secondary industry rose to over $60 \%$ (Figure 3 ). 


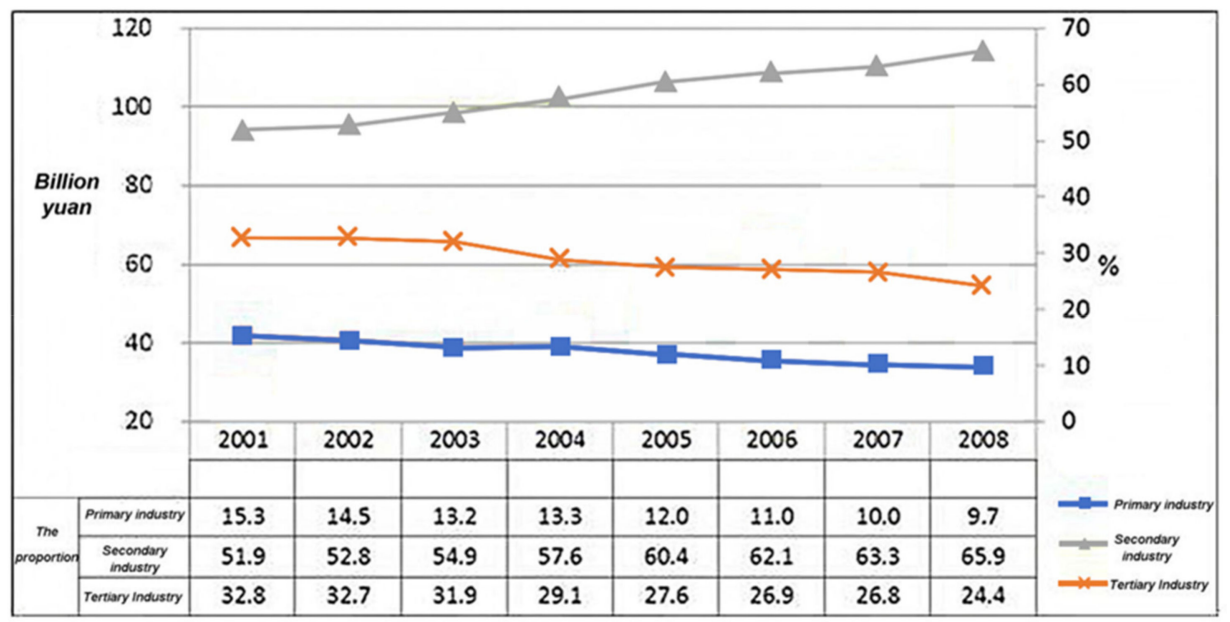

Figure 3. Changes in GDP and Industrial Structure from 2001 to 2008.

\section{Materials and Methods}

\subsection{Data Source}

The data sources of this article mainly come from the following two conveniences.

\section{- Collection of information}

According to the research projects and topics, the literature is obtained by investigating the literature, so as to comprehensively and correctly understand a method for mastering the required research questions. These documents include basic academic papers and government-published documents. The role of the literature review based on academic papers is: (1) to understand the history and current status of relevant issues and to help determine research topics; (2) to form a general impression of the subject, which is helpful for observation and access; (3) to obtain comparative data; and (4) to provide a full picture of the research topic.

\section{- Social research and interviews}

This study used a mixed method of research, through informal interviews to visit local residents and workers for face-to-face discussions or a questionnaire in urban areas and mining areas. Additionally, the study held formal discussions and collected information from various government departments and the staff of Pingdingshan Coal Mine Group, and conducted a field trip to each mining area. The data sources for the research questions were primarily obtained from a field survey of Pingdingshan using structured questionnaires. The questionnaire had a total of 11 questions, which were mainly based on single-choice and multiple-choice questions. Certain questions were designed to provide open-ended answers. The interviewees mainly answered 11 established questions on the questionnaire. However, since this was an informal interview, the interviewees were often also willing to have conversations about related issues while answering the established questions, such as divergent expressions of ideas, own stories, etc. These contents were also recorded for reference. Considering the differences in the concepts of different groups of people, open topics are more likely to find potential causes and provide more depth of understanding. The interview approach was also used to discover new problems and find reasonable solutions. Wengraf emphasised that it is essential to consider the needs and understandings of different groups of people, so the interviews and questionnaires were expanded as much as possible to narrow the gap between the actual situation and the data obtained [40]. In addition, the classification of the results obtained provides an intuitive and in-depth understanding of the objective facts of public demand. Despite this, in the actual data collection process, respondents sometimes did not fully answer questions and were selective in the information they disclosed, resulting in reduced effectiveness in the data collection process. Therefore, it was necessary to guide and explain the respondents when necessary to obtain accurate data. 
In any research, ethical issues that may arise during the process of the study need to be considered to protect the privacy and autonomy of the participants [41]. Because this study mainly used interviews and questionnaires to collect data, it was necessary to consider possible ethical issues. An ethics approval form was provided by the School's Research Ethics Committee (SREC) from Cardiff University and signed by the instructor (the ethics approval form is shown in the Appendix A). The questionnaires and interview questions did not violate the privacy of the respondents and respected the rights, needs and wishes of others. Interview participants were told that they may terminate the interview at any time [42].

In the selection of the participants, we considered many factors, such as the balance of the number of participants, the area covered, age distribution, occupation, education level, etc., to achieve as comprehensive data collection as possible, so that the data is more supportive and persuasive. The survey time was 27 June-2 July 2018. This interview was mainly aimed at residents of Pingdingshan. Among them, there were 100 surveys of family members in the mining area, 101 surveys of citizens in other areas, and a total of 201 people were interviewed. Among them, 35 were under 21 years old, 69 were 21-40 years old, 68 were 41-60 years old, and 29 were over 60 years old. In addition, among the 201 persons, 124 interviewees were engaged in or indirectly engaged in coalrelated industries, accounting for about $61.7 \%$ of the interviewed persons. There were also some people who switched to other occupations after layoffs due to the downturn in the coal industry. This data is not included in the 124 people (the questionnaire is shown in the Appendix B).

\subsection{Research Design}

The issues under investigation in this study are how to use public demand to guide the protection and reuse of industrial heritage and how to coordinate the development of industrial heritage and public participation. The focus of the research is on public participation, public needs, and ways to protect and reuse industrial heritage. To answer this question, it is necessary to delve deeply into social events. The main body of research is the direct interest groups of industrial heritage protection and reuse, specifically ordinary people who are neglected in the planning process. This study collected data in the context of the Pingdingshan mining area protection plan, in order to answer the research questions:

1. With regard to residents' sense of belonging and local consciousness, can the spiritual awareness of these citizens help the sustainable development of industrial heritage?

2. What is the impact on industrial heritage protection planning if there is little or no public participation?

3. Can planning to consider from the public's needs help to solve some of the social problems arising from urban industrial transformation?

In response to these research questions, a research hypothesis is that the protection scope and protection methods of industrial heritage protection and reuse require public participation and guidance. The scope of protection includes how to decide which part needs to be fully protected, which needs to be reused, and which needs to be demolished and built. The protection method includes the protection intensity of the industrial heritage, how the public participates, and how various complex interest groups coordinate organically to realize the protection action together. This hypothesis comes from a combination of theoretical support and observation and analysis of social phenomena. Through repeated argumentation in the discussion stage, the corresponding conclusions are drawn to answer the original research question.

\section{Results}

\subsection{The Status of Coal in the Lives of Residents of Pingdingshan}

Coal mining has a special meaning in Pingdingshan, and has an important position as a symbol of the city, creating a sense of place. Firstly, from the perspective of history and culture, planning data reveal that Pingdingshan is a city that has developed and thrived 
because of coal. It was one of the first coal mining cities in the PRC, and it has witnessed the history of China's coal mining industry. In other words, coal mining is a witness not only to the development of Pingdingshan city, but also to the Pindingshan industrial period. Coal mining is part of the culture of the city and has continued from 1954 to the present, and will continue to be passed down in the future.

From a social point of view, the social impact of coal in Pingdingshan is very farreaching. According to government officials, $70 \%$ of residents in Pingdingshan are currently engaged in mining-related industries, such as miners, logistics personnel, and management personnel. In addition, among the 201 respondents who completed the survey, more than half were in coal-related occupations (Figure 4).

\section{Occupational classification statistics of respondents}

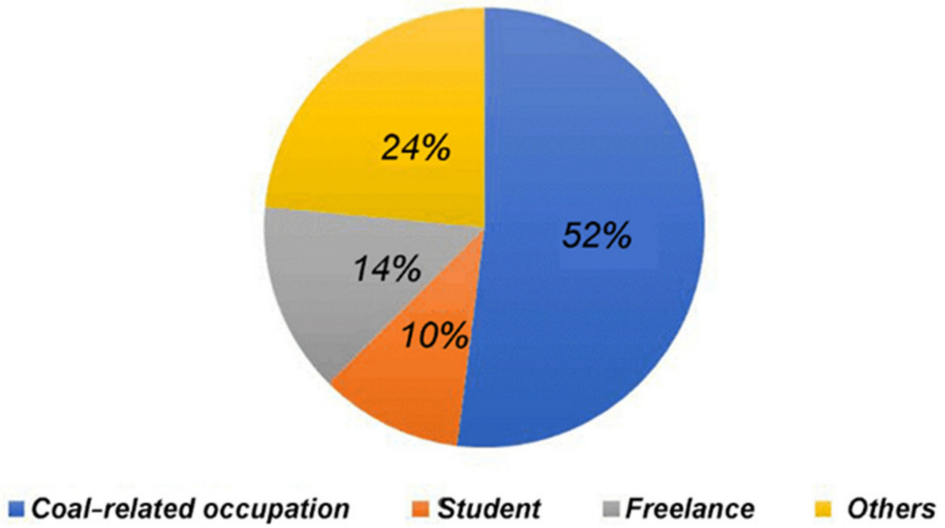

Figure 4. Respondents' occupational classification.

The data reveal that for the majority of residents, accounting for $72 \%$ of the total number of people surveyed, their first impression of Pingdingshan was of coal. The second most frequently cited impression was of the local environment, accounting for $17 \%$ of the total. Finally, $11 \%$ of the people surveyed, their first impression was of Pingdingshan's economic development (Figure 5).

According to the local planning materials, the residential areas of Pingdingshan were initially built around the mining area, so the existing hospitals, residential areas, business districts and other ancillary services are inseparable from the mines. From an economic point of view, most of the economy in Pingdingshan is reliant on coal development, which has created some large enterprises, such as the Pingmei Group, the Shenma Group, and the Gaoping Group. It can be clearly seen from the Henan Survey Organization National Bureau of Statistics Information Network that from the 1950s and early 1970s, the coal mines accounted for $90 \%$ of GDP and were the main source of economic resources. Now, despite the current industrial transformation and the country's policy of restricting coal mining, the economic income from coal mining and related industries is still the economic pillar of Pingdingshan (Figure 1).

In the interviews, residents said that the environmental problems and economic development of Pingdingshan are related to coal mines. The public generally reflected that the exploitation and production of coal had caused many ecological and environmental problems. Among them, the majority of respondents believed that air pollution was the main problem caused by coal production, followed by those who cited the problem of land subsidence (Figure 6). 


\section{Total number of people interviewed}

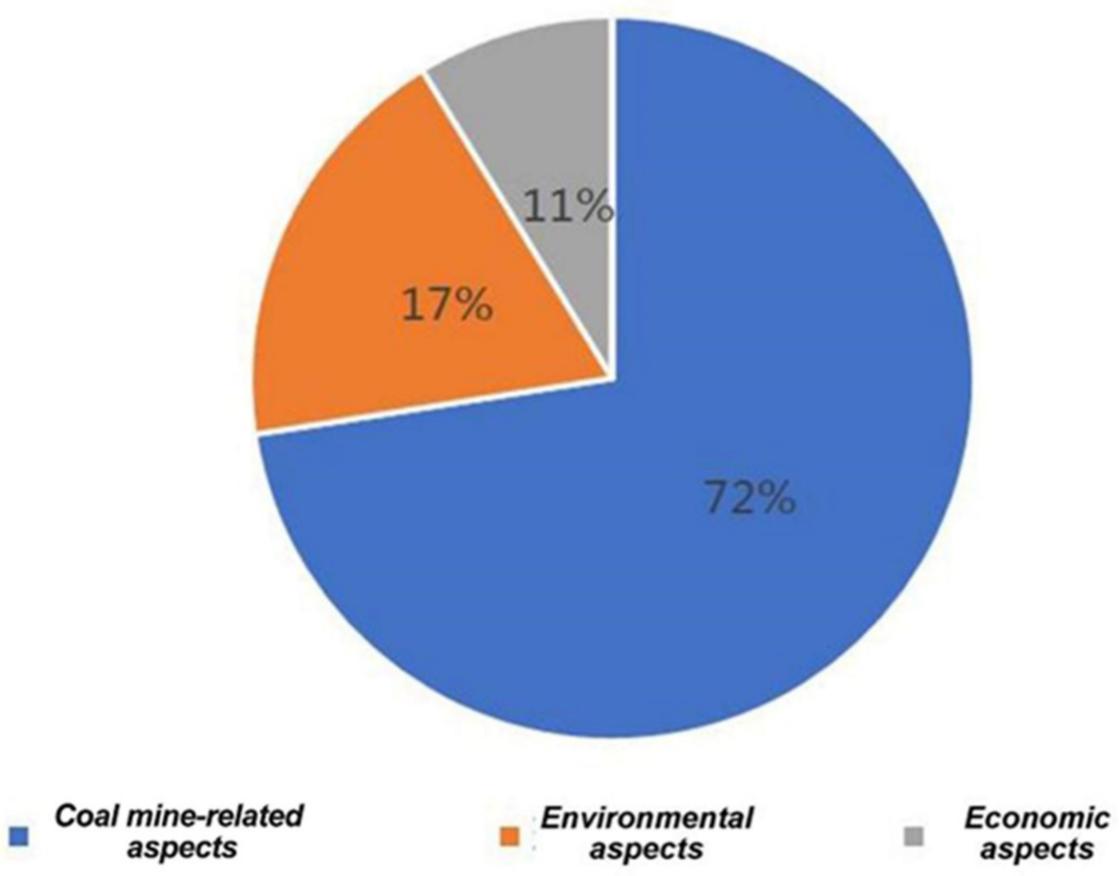

Figure 5. Public impressions of Pingdingshan.

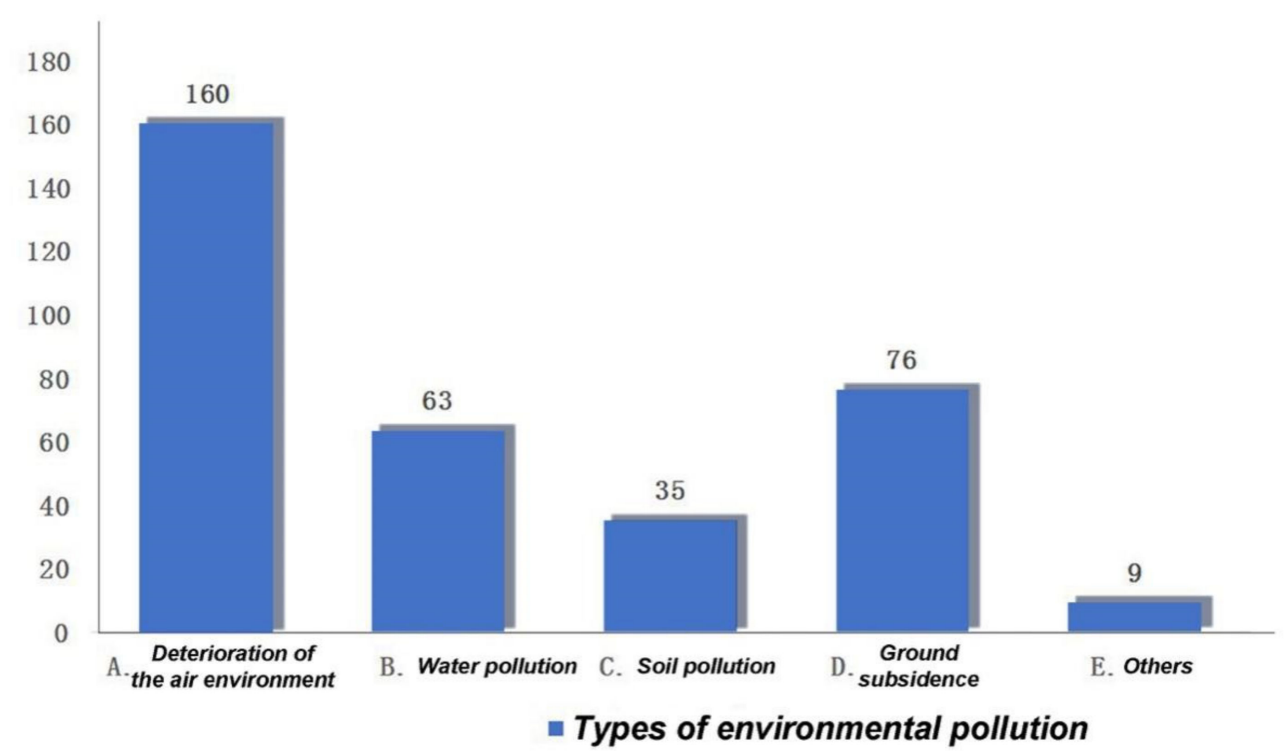

Figure 6. Citizens' views on the main environmental problems caused by coal mining.

Respondents from different age groups gave different answers as to whether coal was important in their lives. Among the respondents who were younger than 20 and 21-40 years old, the majority chose the option "not too important", accounting for $63 \%$ and $46 \%$ of the total numbers of people in their respective age groups. Conversely, among respondents aged 41-60 and older than 60, more people chose "very important", accounting for $65 \%$ and $83 \%$ of their respective age groups (Figure 7 ). 


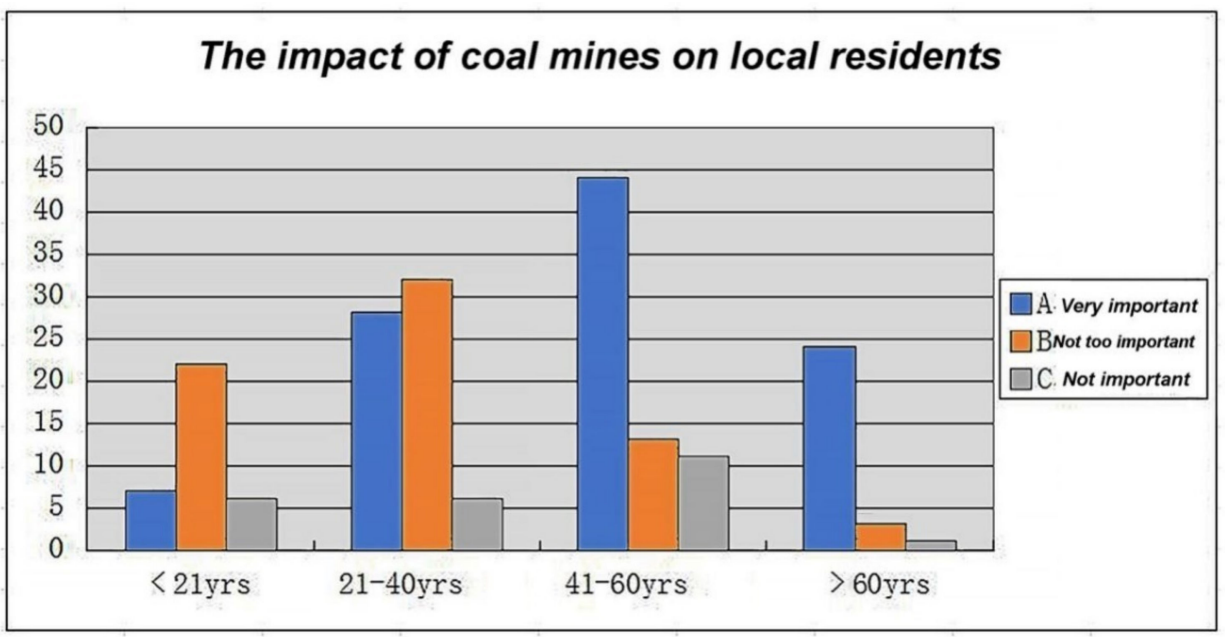

Figure 7. Local residents' statistics on the importance of coal in their lives.

\subsection{The Status Current Status of Coal Mining}

As a major coal producer and consumer, China is also a large carbon emitter. Since the signing of the Paris Agreement in 2016, China has strictly controlled its energy consumption and carbon emissions, and accelerated its economic transformation. China's coal consumption peaked at 4.24 billion tons in 2013 , and has decreased at a rate of $3-5 \%$ per year in recent years, as shown below: $2.9 \%$ in $2014,3.7 \%$ in $2015,4.7 \%$ in 2016 , and $1 \%$ in the first half of 2017. In 2016, coal consumption was 3.9 billion tons, compared with 1.81 billion tons in the first half of 2017. Similarly, the annual coal mining volume is also decreasing (Figure 8) [43].

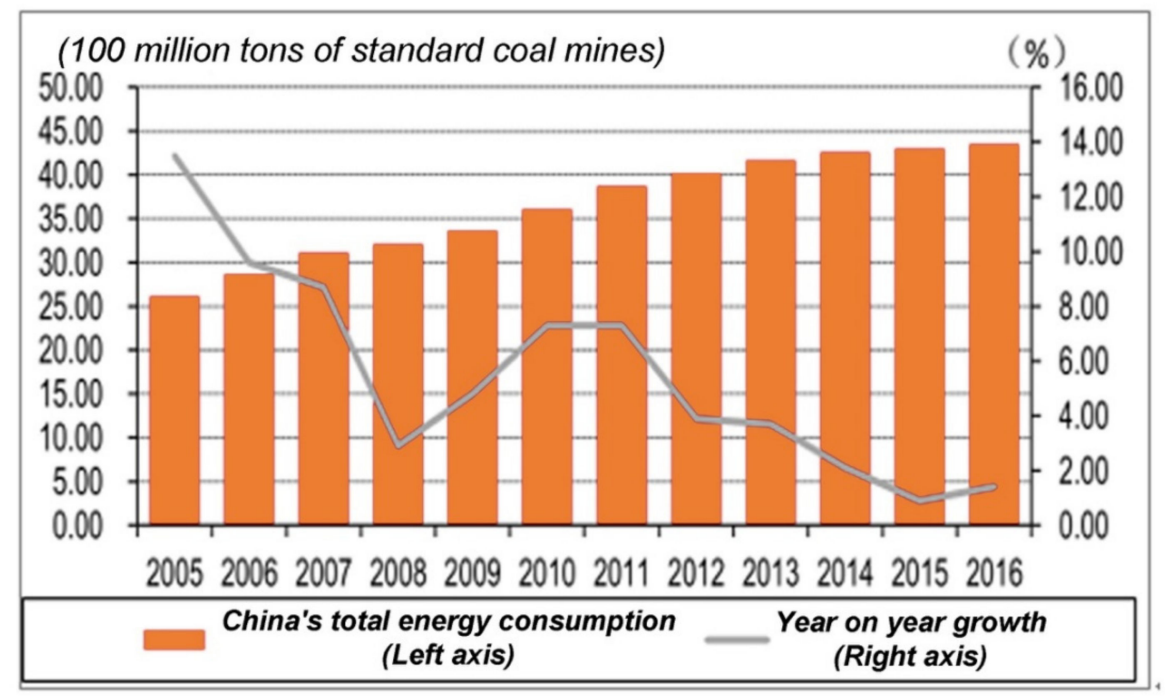

Figure 8. China's coal consumption and trends from 2005 to 2016.

Therefore, under the national policy, mining companies across the country began to control the amount of mining, and at the same time began to close some mines. Pingdingshan Coal Mine faces the phenomenon of reduced or suspended production. Although most of the minerals in the Northern mining area of Pingdingshan are still in production and have a long service life, after the actual research and feedback from the coal mine group, it is known that the third and seventh mines have stopped mining and production. The third mine has been handed over to the sixth mine for management, while the seventh mine has only retained some of its plants and equipment for use in the coal washing plant. According to interviews with employees in the mining area, the second mine was almost 
exhausted in the early years. As the first pit in Pingdingshan, it is very representative and symbolic. The Pingmei Group internally decided to transfer part of the mining area of the surrounding mines to the second mine so that it could continue mining.

\subsection{Industrial Heritage Protection and Reuse Project}

In the symposium with the Pingmei Group and the government, all parties mentioned the plan for a mine park coordinated by the government and the Pingmei Group. According to the Pingding Mountain Urban Green Space System Plan, this mine park is planned in the northern part of the city and will have a total area of 55.5 hectares. The planning of the mine park is based on the protection of mining relics and landscape development, to reflect the industrial and mining culture of Pingdingshan as a coal-carbon industrial city. The goal is to specialize in a combination of mining culture tourism, urban leisure and holiday tourism, and coal field geology education [44]. In this plan, the third and seventh mines will become major parts of the mining park. Since the project was proposed in 2012, many design companies have been invited to put forward numerous design solutions. However, for various reasons, the final design has not been determined. The main reason for this, according to the officials of the Planning Bureau, is that the government is underfunded. On the other hand, from the third mine seminar, we learned that the land of the third mine is no longer to be used for this project and that there are new plans. The Pingmei Group Company has decided to use the land as the site for a new school: the Party School of China Pingmei Shenma Group.

\subsection{Lack of Green Space in Residential Areas}

The green space in Pingdingshan City is divided into the following types: green park space, green production space, protective land, affiliated green space, and other green spaces. In 2000, the urban green space comprised only 232.36 hectares, and the per capita green area was only $3.8 \mathrm{~m}^{2} /$ person. At present, the total area of green garden space in Pingdingshan City is 2023.4 hectares, the green park area is 663.5 hectares, and the per capita green park area is $9.1 \mathrm{~m}^{2}$ / person, the green land rate is $32.5 \%$, and the green coverage rate is $37.6 \%$. The total area of green park space is 663.5 hectares, and the per capita park green area is $9.1 \mathrm{~m}^{2} /$ person. The total area of the green regions in the Northern mining area is 154.31 hectares, and the per capita green area is 7.77 square meters per person. This includes the East Park Par of the 12th Mine of the Comprehensive Park. As shown in Figure 9, the green space system structure in Pingdingshan is not clear, and the distribution of green space is not balanced. There is a lack of green space in the old city, and the total amount is insufficient. There is a severe lack of public green space in the residential area [44].

Ozguner and Kendle explain that in the past few decades, people's attitudes toward the environment have changed rapidly, reflecting the environmental awareness of professionals and the public [45]. Pingdingshan is a city with coal mining as its economic pillar, but in recent years, under the propaganda of national environmental policies, residents have developed a clearer understanding of their living environment. In the survey of residents' intentions for the future mining area, it was found that all age groups are eager to transform the mining area into a park or a mine site park (Figure 10). This also reflects the residents desire for green and leisure space. The government's planning documents that although the overall per capita greening of Pingdingshan has been improved recently, there remains an imbalance in the distribution of green space, and a particular lack of green space in residential areas [44]. It can be seen from the "Ecological status map of the Northern mining area" that the northern region has a wide range of subsidence areas, and a large part of this area is residential; green space in these residential zones is very rare. However, there is a large green park in the middle of the subsidence area-East Lake Park (Figure 9). According to the government planning documents, this is a case in which the government reformed the subsidence area into a wetland park. Donghu Park, which is located in the west of Donggong Town Street. This was originally a coal mining area. After the coal was 
mined, the incoming water formed a lake. The 12th Mine of Pingmei Group transformed it into Donghu Wetland Park. At present, its total area is close to 15 hectares, and it is listed as one of the eight scenic spots in Pingdingshan City [28].

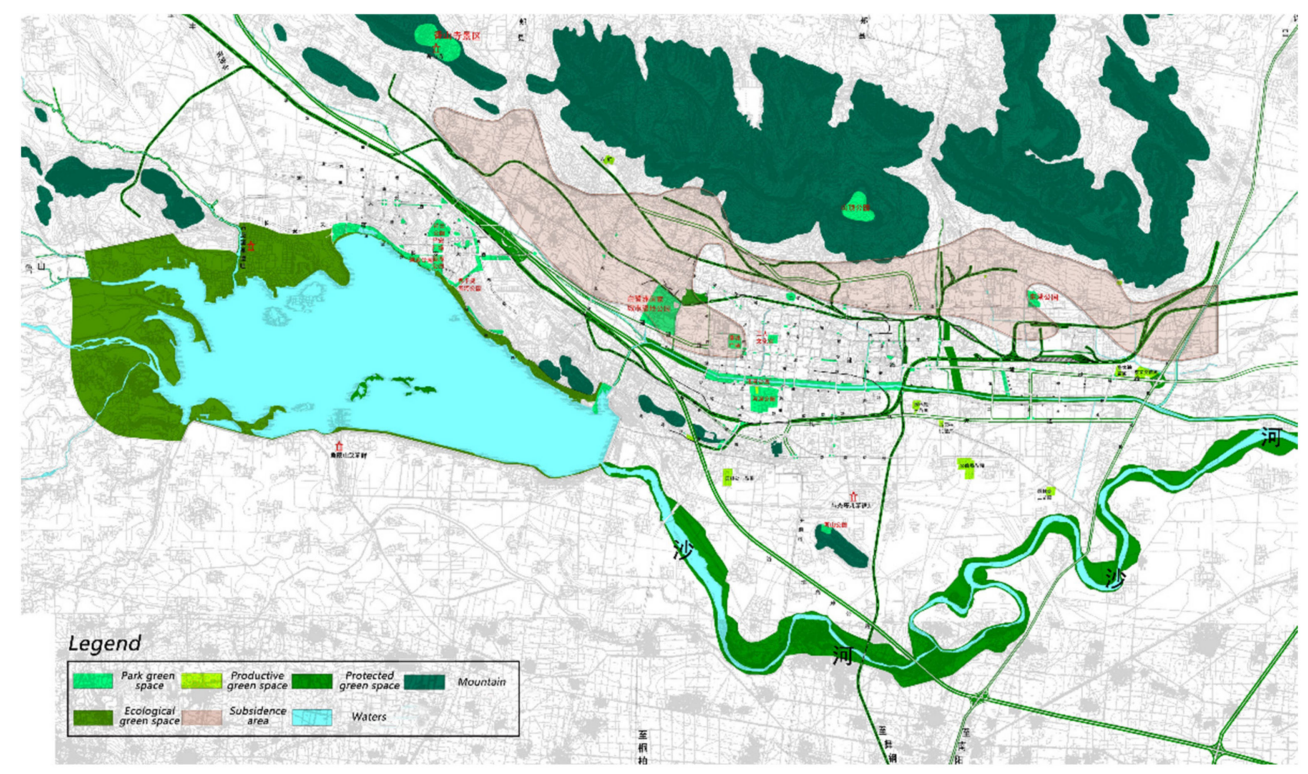

Figure 9. Ecological status map of the Northern mining area.

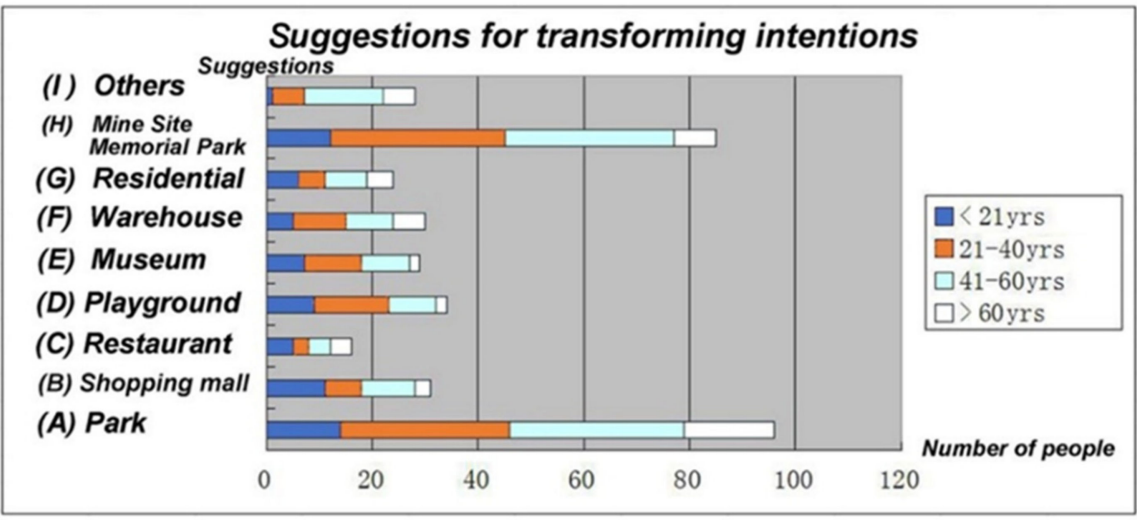

Figure 10. Residents' hopes for transforming the mining area.

The same case also has the Bailuzhou Wetland Park far from the urban area. Bailuzhou Wetland Park is located in the western part of the city; it covers about 90 hectares and is one of the six national urban wetland parks in China. The area was also initially a subsidence area. As the coal mining did not backfill the goaf in time, it caused settlement and collapse of the ground in the area. In 2005, the Pingdingshan government changed the area into a wetland park according to local conditions.

Often when people decide whether to dismantle industrial sites, they need to consider the reusability of buildings and the impact of industrial development on the local history [46]. For industrially developed cities like Pingdingshan, many environmental problems have been left after years of development. Additionally, these issues are also of concern to the government and the public. As a government and planning creator, it is possible to completely dismantle industrial sites and build sustainable plans, such as more modern and environmentally friendly forest parks. Removal of traces of industrial sites in the local area can quickly improve the domestic environmental situation, reduce pollution caused by industrial development, unrestricted development of new functional areas and the establishment of modern infrastructure systems. It emerged at the government symposium that the government was planning to transform these two wetland parks from the 
perspective of the entire urban ecological environment. Interviews with residents revealed that the acceptance of this project was very high. Loures stated that industrial landscapes, including ecological reality, act as the physical and biological part of the ecosystem, and take the possibility of creative practice and socio-economic realities as factors that contribute to the quality of life in the community [9]. In the existing case of Pingdingshan, the transformation of the subsidence area into a wetland park is considered to be a step that would improve the ecological environment. Although this planning process has no public participation, the plan satisfies the needs of the public. Therefore, its acceptance among the residents is very high. It can be stated that this industrial heritage planning design, which meets the needs of the public, is worthy of being promoted.

Therefore, interviews with citizens and survey data revealed that residents generally expressed hope that the mine can be transformed into a park or industrial park in the future, and support for this plan was much higher than several other options (Figure 10).

\subsection{Lack of Government Policy on the Protection of Industrial Heritage}

In the 13th Five-Year Plan for the development of the Pingdingshan Cultural Relics Museum, the number of cultural relics' protection units increased significantly. According to the statistics of the government of Pingdingshan Cultural Protection Bureau, the city registered 5273 non-removable cultural relics, including 25 national vital cultural relics protection units, 60 provincial cultural relics protection units, 89 municipal cultural relics protection units, 381 county-level cultural relics protection units, and national historical and cultural towns and villages. There are 12 state-owned museums and two registered non-state-owned museums, and the state-owned museums hold nearly 1.8 thousand cultural relics. The plan emphasizes vigorous promotion and education on cultural heritage protection and related laws. It also mentions the government's financial guarantee for heritage protection. In the future, it is necessary to further establish and improve the mechanism of government investment and multi-channel capital investment [47]. However, there is no item on Pingdingshan's industrial heritage in the list of many cultural relics' protection units in Pingdingshan. At the symposium of the Pingmei Group, it was revealed that in the mining area of the Second Mine, there is an exhibition hall called the Pingmei Group Exhibition Hall, built in 1977 and known by mine employees as the "Li Eryin Memorial Hall". The museum was built to commemorate Li Eryin, a heroic worker who died in the mine, and to promote his work and fearless spirit. The exhibition hall was later renamed the "Pingmei group exhibition hall" and used for exhibitions and records of the development and history of the Pingmei Group [47]. Since the exhibition hall is not open to the public on weekdays, the museum data here is all from public interviews. According to the residents of the Second Mine, the hall has a small area and there is no equipment for display production, most of which are pictures and text descriptions. Moreover, the museum is not open to the public, but only for receptions. It is usually used by the Pingmei Group itself, which organises events such as exhibitions of paintings and calligraphy, table tennis competitions, and also for storing materials. In the interviews, most of the citizens who do not live or work in the second mine said that they did not know that there was such an exhibition hall, or that they knew of the hall but they had never visited it because it was not open to the public.

Through consultations with government officials and information searches on government websites, it became clear that the government has little policy and planning content for the protection and reuse of Pingdingshan industrial heritage. The China Association for Science and Technology Innovation Strategy Research Institute and the China Urban Planning Society released the list of China's industrial heritage protection (First batch) and the list of China's industrial heritage protection list (Second batch) in 2018 and 2019 [48,49]. Compared with the list of the first batch of 100 in 2018 and the second batch of 100 in 2019, there is no industrial heritage in Pingdingshan that has been applied for or mentioned. The 13th Five-Year Plan for the development of the Pingdingshan Cultural Relics Museum mentions that Pingdingshan has a large list of cultural relics for protection and a list of 
museums, but none of them are related to industry. During the symposium, an official of the Weguang New Bureau also said: "At present, there is no relevant content on industrial heritage in our existing cultural relics list and museum information." There is no knowledge dissemination related to industrial heritage in the knowledge point promotion section of the government website. In addition, an official from the Planning Bureau said: "Since 2012, there have been plans for building a mining park, combined with the suspension of the third and seventh mines for tourism development and construction: this is also industrial heritage protection." However, officials also said that this plan is still only a blueprint.

\subsection{The Public Lacks Knowledge of Industrial Heritage}

In order to ensure the accuracy of the interview results, the respondents were introduced to the definition of industrial heritage before our interview. By collating the interview data, it can be seen that those interviewees who oppose the preservation of industrial heritage have mostly given the following reasons: coal mine production is polluting the environment, so shutting down the disused mine is better in ecological terms; mines that have been abandoned and can no longer be mined are a waste of resources; and it is better to transform to other industries to produce more significant benefits. At the same time, those who agree to preserve the industrial heritage said that mines are the place where they worked all their lives, and they will feel lost when they are removed.

The questionnaire asked residents whether they would feel regret if the mining buildings and equipment were dismantled (Figure 11). Initially, more than half of the respondents replied that they would not, because they only considered this issue from the environmental and economic aspects. However, as shown in Figure 12, respondents of all ages did not understand the protection of industrial heritage or even the concept of industrial heritage. After a brief explanation by the interviewer, $94 \%$ of the respondents thought it was necessary to protect and reuse the Pingdingshan mining area (Figure 13). This shows that residents generally lack knowledge of industrial heritage and its protection and reuse. The reason for the protection and reuse of the Pingdingshan industrial heritage was explained by the Pingmei Group: "The coal mines in the Northern mining area have an average of 30 years of mining service time, and most of the mines and equipment here are still working. So, the protection of industrial heritage will not be considered until most of the mines are closed."

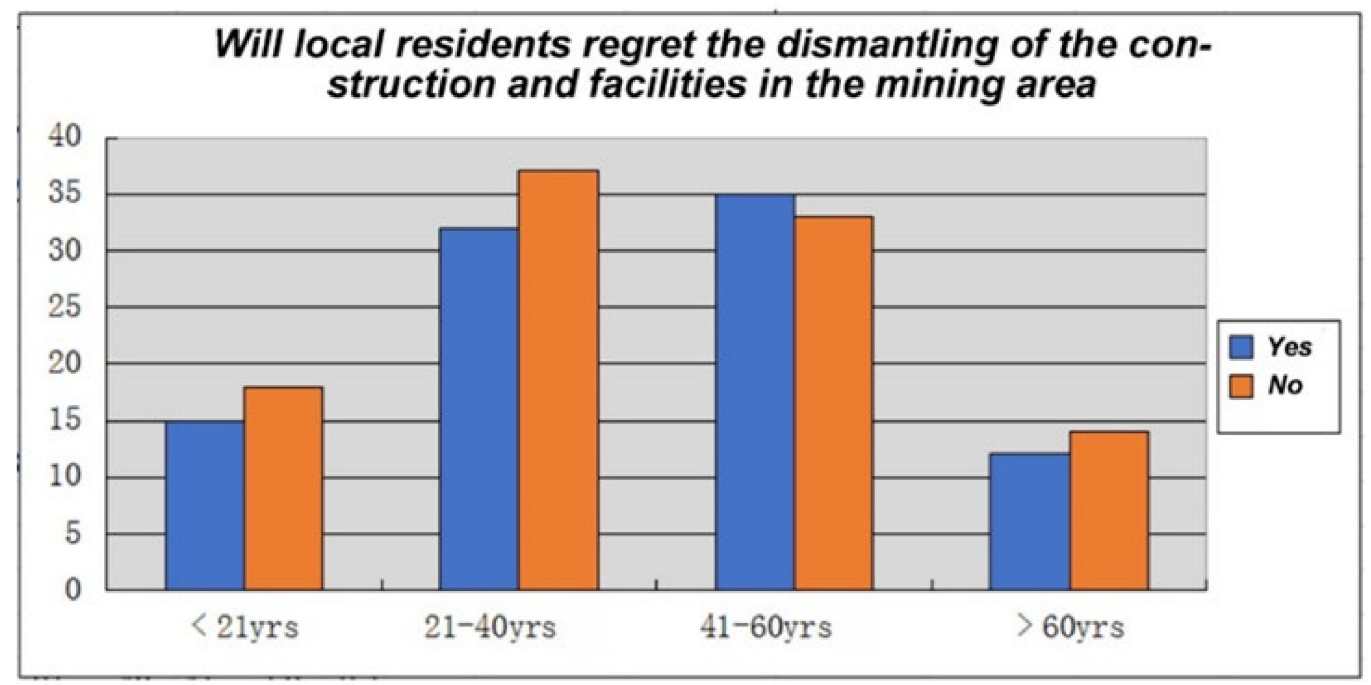

Figure 11. Whether residents would regret if the buildings and equipment of mining be dismantled. 


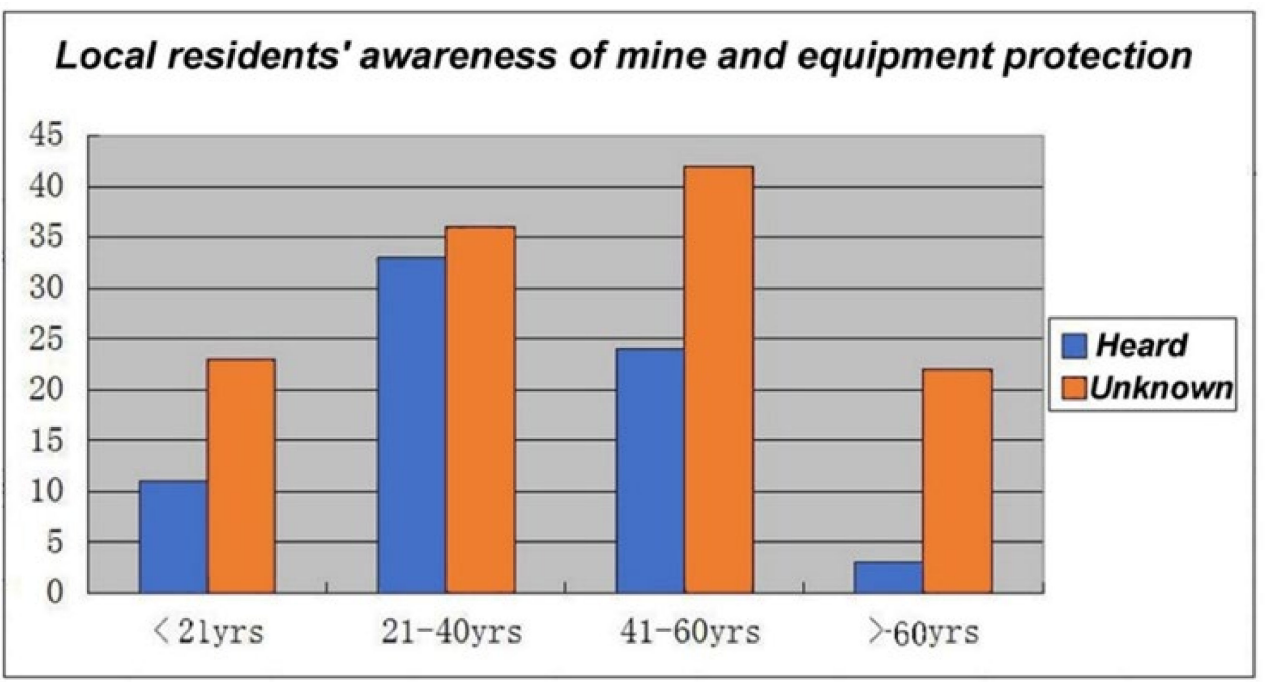

Figure 12. Does the resident have knowledge of the concept of protection of industrial heritage?

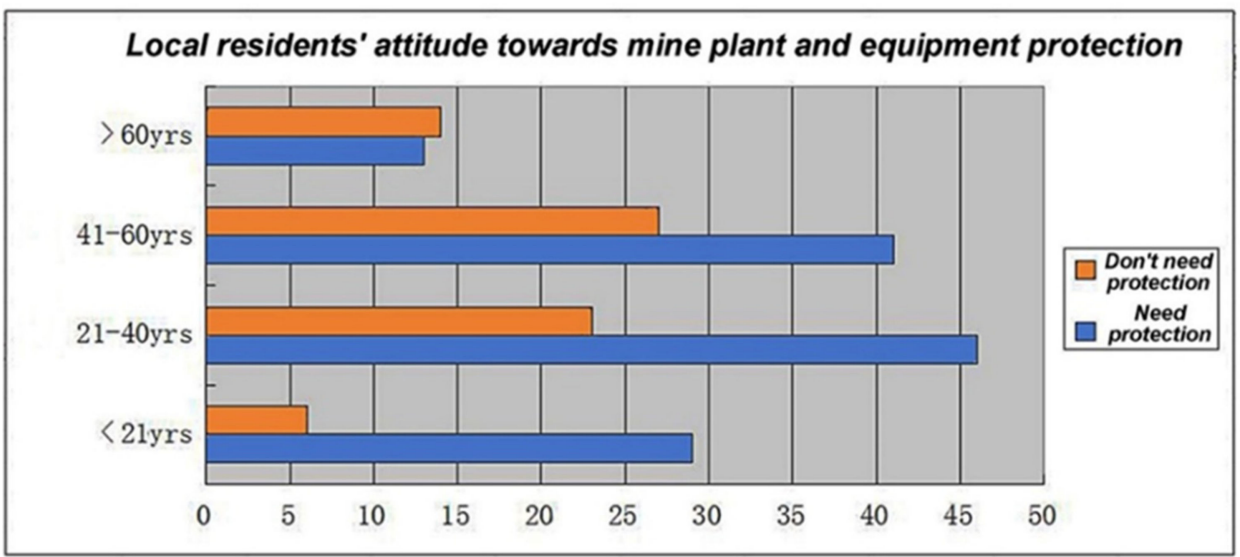

Figure 13. Residents' attitude towards the protection of mines and equipment.

As shown in Figure 11, when asked whether they would feel regret it if the buildings and equipment of mining were dismantled, $51 \%$ of the respondents said they did not think they would regret it. However, unlike the other age groups, more respondents aged 41-60 indicated that they would feel regret.

Respondents cited the following reasons for their responses: coal mine production is polluting the environment, so shutting down the disused mine is better in ecological terms; mines that have been abandoned and can no longer be mined are a waste of resources; it is better to transform to other industries to produce more significant benefits; and mines are the place where they worked all their lives, and they will feel lost when they are removed.

In general, local residents had less knowledge about the protection of mining areas. Regardless of the age group, the number of respondents who did not know about industrial heritage protection exceeded the number who did. When asking this question, the concept of industrial heritage needed to be explained or examples given to help residents understand (Figure 12).

Overall, after they had been given a brief outline of the concept of industrial heritage, the number of interviewees who thought that factories and equipment in the mining area should be protected increased: $94 \%$ believed that they should be protected (Figure 13).

Among those who believed that industrial heritage needs to be protected, the questionnaire asked about the different types of value of the mining area and equipment. People over the age of 21 highlighted the emotional value in the old mining area. Secondly, most people of all ages believed that old mines and equipment have social protection value. 
Compared with these two options, fewer people regarded the old mines as having economic value (Figure 14).

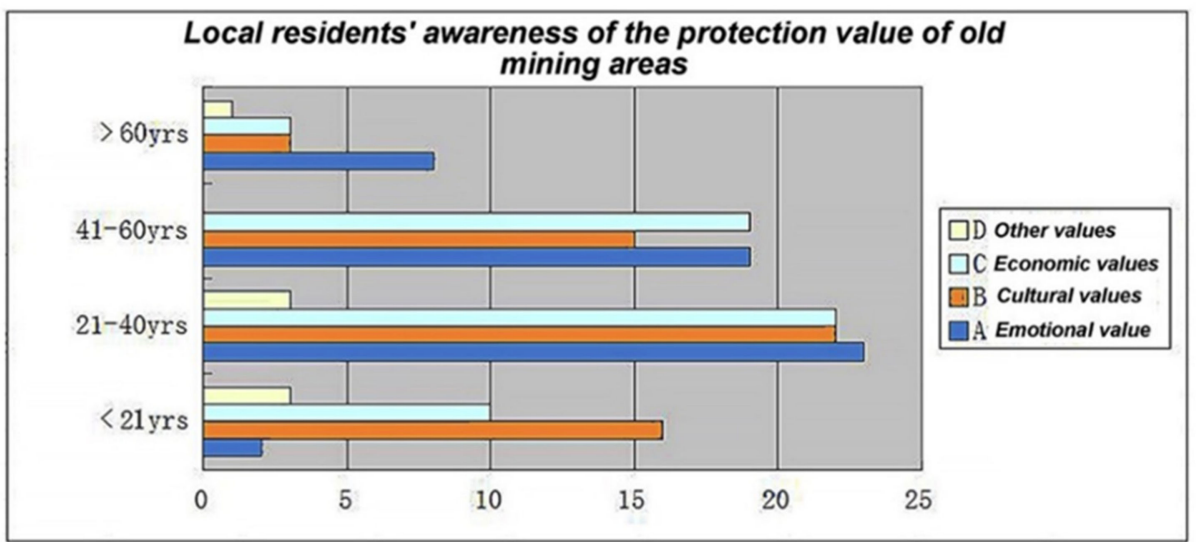

Figure 14. The value of old mines and equipment considered by residents.

\subsection{The Willingness and Participation of Residents in the Future Plan}

Fiorino describes public participation as the participation of people outside the government's decision-making process [50]. Britton states that public consultation includes education and information shared between decision-makers and the public to make more informed decisions [51].

In the interviews, respondents were asked whether the suspension of the future coal mines in Pingdingshan would affect the lives of local residents. Almost all interviewees mentioned that unemployment would be a problem, and most of these people were worried about the future economic development of Pingdingshan. Among the respondents who were engaged in coal-related occupations, more than $70 \%$ cited re-employment intentions in tourism-related industries and new energy industries; this was higher than the number who reported that they would seek re-employment in the new energy industries (Figure 15).

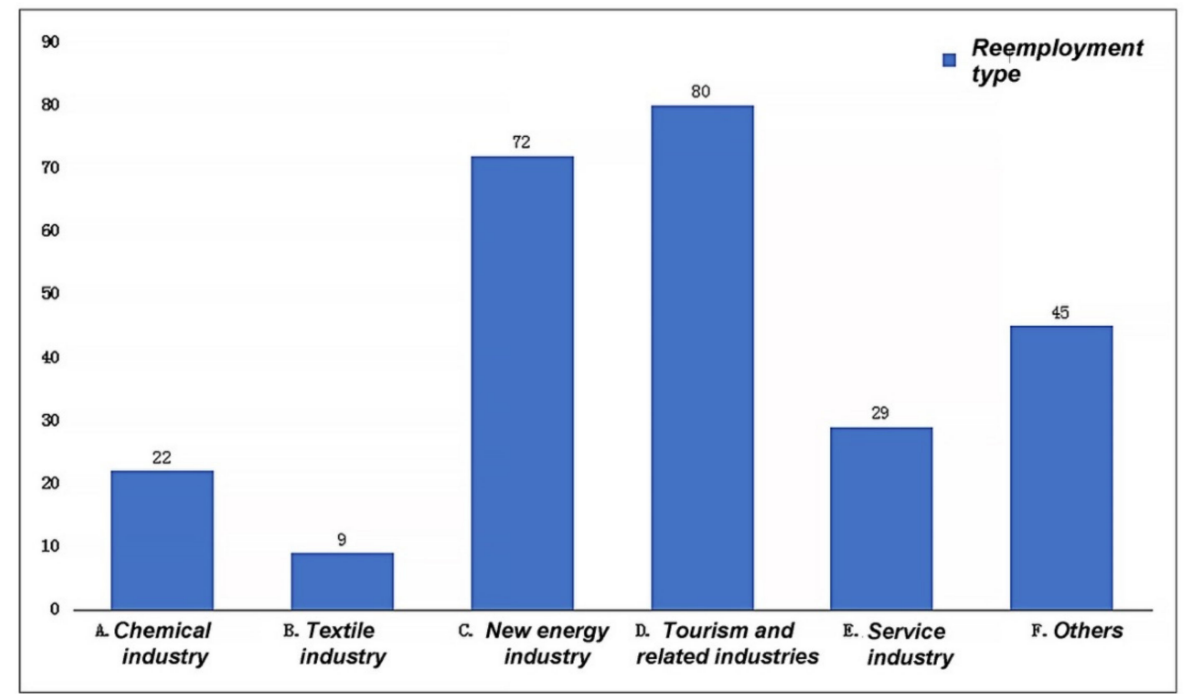

Figure 15. Residents' intended re-employment.

In the survey, if these coal mines were transformed into tourist attractions or business districts in the future, $86 \%$ of respondents expressed their willingness to participate and consume these offerings, while $14 \%$ indicated that they might not attend such attractions or were not interested (Figure 16). 


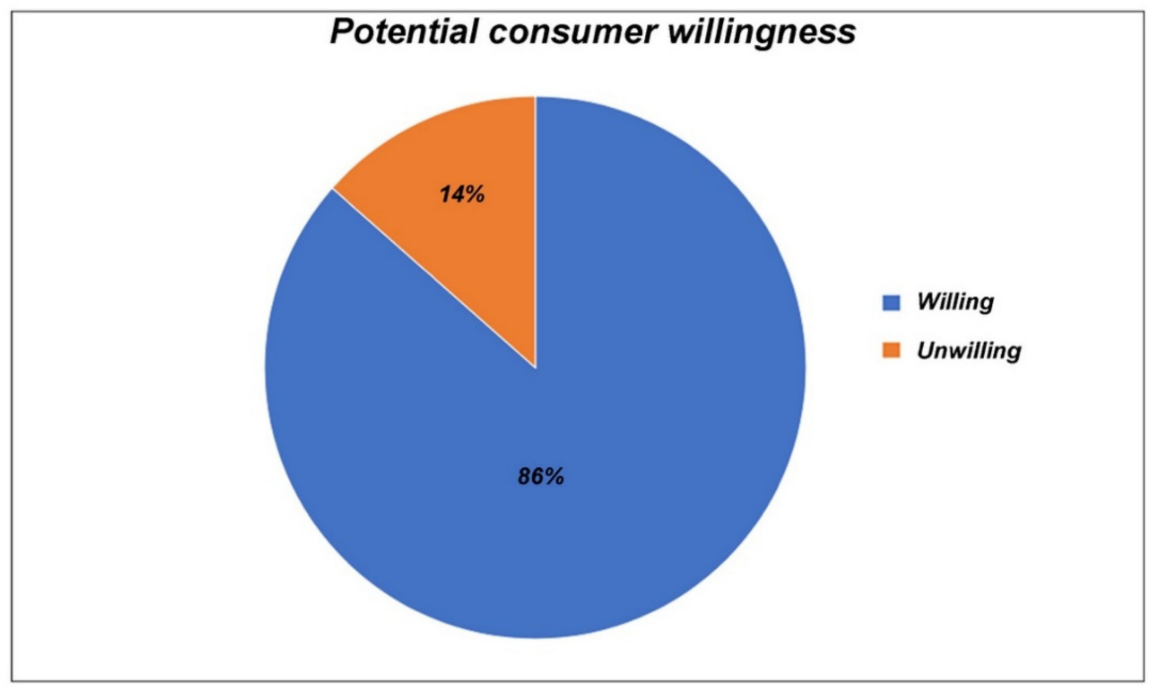

Figure 16. Residents of the potential consumer willingness.

On the Pingdingshan Government website, on 8 January 2018, four design proposals for the "Planning of the Ecological Restoration and Cultural Recreation Area of the Northern Mountain of Pingdingshan City" were publicized. These four designs were released to the public and solicited opinions through the Pingdingshan Daily, a live demonstration on the first floor of the Municipal Museum, the website of the Urban and Rural Planning Bureau, the Pingdingshan Planning WeChat platform, and the Pingdingshan Micro Newspaper. The website states that the final plan will be voted on based on a combination of expert reviews, relevant departments, and public opinion. Subsequently, the website provided a way for public participation: visit the website of Pingdingshan Urban and Rural Planning Bureau (www.pdsgh.gov.cn, accessed on 28 August 2018) to browse the design plan and vote through WeChat on Pingdingshan Planning and WeChat on 1 December 2017 (source: http:/ / www.pds.gov.cn/contents/1035/52831.html, accessed on 28 August 2018) [52].

However, although government agencies provide channels for public participation, the public has not received much feedback on them. From questionnaire surveys and interviews, the public does not understand these plans, nor is it clear about the feasibility of voting. At the same time, some of them are unwilling to participate in them and directly submit their own opinions to the relevant departments. Mr. Wang said, "Our residents do not understand these plans. Those plans have no harm for us-that is OK." They seem to lack the interest and awareness of the protection of historical sites. They think that as long as they are harmless to them, they have nothing to do with them. They do not want to take the initiative to understand, even if the government has provided some channels. In addition, the residents also reflected many other problems and wishes, but when asked if they had provided their opinions to the government and the planning department, most of the residents said that they had not. Mr. Dong said, "As civilians, we have wanted to express some opinions to relevant government personnel, but there is no suitable channel to respond to such incidents." Ms. Yang said: "I didn't go to the government to give advice. And I don't know who to advise. Even if I give my opinion, they won't necessarily listen. Finally, no one has asked us." The person in charge of the Pingmei Group also said: "The Pingmei Group has no plans for the suspension of mining areas. The government plans to do so. Our group will cooperate with the implementation."

Through this information, it appears that citizens are willing to express their opinions in interviews, but they are not enthusiastic about proposing these opinions to the government. They feel that their right to speak is inadequate, and that, ultimately, their opinions will not be heard. Moreover, most of the respondents indicated that they were not consulted about the current government plans and projects or invited to participate in relevant forums. It is not difficult to see that the government's decision-making mechanism 
has led to public participation not being effectively reflected in the plan. Through current decision-making methods, it can be found that most of the planning projects are planned by the government and passively accepted by citizens. Although the above information indicates that the government provides several channels for public participation, actual participation in these channels is not high enough, and public participation is only invited in the later stages of design and planning. For example, the existing planning scheme mentioned above opens a voting choice to citizens. This is not directly involved in the design and process participation decision, so that the public's demands are ultimately not passed to the planners and planning departments. The extent of community involvement depends to a large extent on the local political structure and the extent to which it allows and promotes the participation of community members [53-55]. Although the concepts and measures of public participation have been proposed by the government and the planning department, actual public participation is not high. On the other hand, in the pre-planning and the process of planning and policy development, the elite consciousness is the main guide. Public participation occurs mainly in the later stage, and residents have no actual power in planning and policy formulation, while their decision-making power is also weak. Moreover, planning led by the elite consciousness is more concerned with political, cultural, and economic aspects, and it is rarely conducted and designed from the perspective of public demand. Through the analysis of the SenStadtUm model (Figure 1), the level of public participation in Pingdingshan City can be classified as secondary, collaborative, passive, and mandatory participation.

\section{Discussion}

Through the analysis of the previous data, the public's wishes can be explored. Studying the public's wishes is an important basis for industrial heritage protection and reuse planning and design. Public desires cover a range of different aspects, all of which should be considered in the planning and design of policies.

\subsection{Spiritual Needs: Residents' Sense of Belonging and Local Sense of the Sustainable Development of Industrial Heritage}

The term "place identity" has been discovered and used since the late 1970s [56]. It is described as "a hodgepodge of memories, concepts, explanations, ideas, and related feelings about specific physical environments and types of environments". These elements can be divided into two categories; one category includes memory, values, thoughts, concepts, and environment, and the other category includes the relationship between different environments: family, community, and school [57]. Then a "sense of belonging" was created for the specific environment (such as the street or building in which people grew). Many researchers believe that place attachment is a complex multidimensional structure, although there is no general consensus on what these dimensions are [58]. Various studies have distinguished place dependence [59], place identity [60], social bonding [61], and affective attachment [62]. Due to the lack of clear measurement content, it is difficult to generalise from one study to another, which has led to criticism of the lack of a unified definition of place attachment [63]. Trentelman said that one way to simplify the concept of place attachment is to keep it as a connection with a physical place, which is different from a connection with people, which is more suitable to be described as community attachment (something that sociologists often study) or social capital. [64]

The industrial landscape describes an important part of local history, and as such, it constitutes a testimony to cultural, social, and economic concepts and evolution, recording and explaining the important value of urban heritage [14]. Cho and Shin (2014) also state that there are undoubtedly historical, modern, natural, and cultural features in the industrial heritage that have special significance and contribute to the creation of "local sense" [65]. Ardakani and Oloonabadi talk about the long-standing cities, the social and cultural values they represent, and their role in defining local feelings, community belonging, and social cohesion. These material and social attributes are indivisible; therefore, attention should be 
paid to the tangible and intangible aspects of heritage, namely the emotional and spiritual needs of the population [66]. Some scholars also view industrial heritage as a collective memory of local citizens, which can represent social and cultural values and their role in defining social cohesion and social consciousness [67]. In other words, the local industrial heritage is not only the emotional carrier of the residents' sense of belonging and local sense, but also a public appeal. Coal mining has these special meanings in Pingdingshan, and has an important position as a symbol of the city, creating a sense of place. The information obtained from the questionnaire shows that coal is the first impression of the area cited the residents of Pingdingshan City, in addition to the environmental pollution and economic development problems of Pingdingshan (Figure 5). However, the memories shared by local people may not always be positive [68]. In this case, environmental and economic problems are inseparable from the local coal industry. For example, many residents mentioned environmental pollution, land subsidence, etc. (Figure 6); furthermore, the coal-related secondary industry, which has been the primary source of Pingdingshan's economic income since the 1950s, has undergone various transformations and policy changes, although it is still the backbone of Pingdingshan's financial income (Figure 3). In the local area, with the exception of people younger than 21 years, who think that coal is not important to them, most of the remaining respondents believe that coal has a significant impact on their lives (Figure 7).

To better understand why residents have such high dependence on coal, the occupational distribution of residents revealed that more than half of the respondents were engaged in coal mining and related occupations (Figure 4). The same information was conveyed at a forum with the government: the relevant leaders said that about $70 \%$ of the population in Pingdingshan is engaged in coal mining and coal-related occupations. As David puts it, people's emotional needs for their places of life can be summed up regarding "local attachment" or "historical identity". "Place" is a core concept in the social sciences. It is the "environment" of individual activities or experiences, wishes, etc., in space [69]. Therefore, coal mining and related industrial equipment and places provide emotional support for residents and serve as a symbol and source of the local sense of belonging and local feeling. Residents of Pingdingshan regard coal as a symbol of their city and a part of their long-term life. Such feelings are fully integrated into their flesh and blood, and are not easily removed. Moreover, these emotions are not unique. In the interviewed population, the carrier of the emotion of coal is the shared memory of the people in this region. Its large-scale appearance means that it eventually becomes an emotional attachment for the local people: that is, a sense of belonging and a sense of place. Therefore, public participation is important in meeting people's emotional needs. From the perspective of civic participation, the protection of industrial heritage is conducive to respecting the wishes of residents, improving the protection of historical heritage, and retaining awareness of the historical background and emotional inheritance. Conversely, when planning and designing the protection and reuse of industrial heritage, it is necessary to satisfy and retain the "feeling" and "local sense" of the residents. For example, planners should listen to residents' suggestions and plan to retain the mines and equipment that they consider to be important and symbolic.

As Swensen said, heritage conservation can help to develop the regional character of a city. A large number of practical theories and cases prove that people are more inclined to protect and reuse industrial sites [11]. Through the previous analysis, we know that the current planning goals of Pingdingshan and the public's emotional needs for the mining area are far apart. By re-integrating the coal industry culture as a core element of Pingdingshan, you can directly use many existing resources, reorganise and configure them, and transform their functions to make the planning process more economical and environmentally friendly. In addition, the industrial transformation of a city is often closely related to culture. With the inherent affinity of heritage culture, residents can better accept, transform and develop culture, establish new industrial parks and cultural facilities, and can influence heritage culture as a city card. 


\subsection{Enhancing the Social Acceptability of Planning through Public Participation}

Yang states that in the process of protecting industrial heritage, the appeals expressed by public participation often contradict the local elite consciousness: this bringing certain obstacles to the planning process [70]. He believes that policy-makers cannot satisfy all the needs of the community. Marzuki reports that in most developing countries, the political structure is concentrated and operates via a top-down bureaucracy [71]. Politicians and policymakers are reluctant to share power with the public, making it difficult or impossible to participate spontaneously in community activities [37]. In the questionnaire, residents support for the transformation of mines shows that there is a high demand for green space and public leisure space (Figure 10).

On the other hand, in the symposium with the government, relevant officials said that these areas would be transformed into new industrial land and commercial areas in the future to promote the development of the local economy. Therefore, as shown in the survey statistics, although $86 \%$ of people are willing to go to these business districts, $14 \%$ of respondents are not interested in them (Figure 16). Moreover, in the planning of industrial heritage protection and reuse, a plan without public participation is not necessarily without social acceptance, but there will be a certain degree of negative reaction. These data highlight that there are contradictions and gaps between public participation and elite awareness. Through the analysis of the public questionnaires and interviews, results proved that the public is dissatisfied with the lack of green spaces in the existing environment; at its roots is the public's need for fair use of space. As stated by Faga, transparency is an important part of all fair processes, including openness and honesty [72]. Industrial heritage includes buildings, machinery, workshops, factories, mines, warehouses, and all underground structures and locations, which were initially non-open spaces [3]. Industrial heritage can be protected and reused in many ways [18]: building a museum on the original site, transforming the original site into a landscape park, or undertaking comprehensive development combined with shopping and tourism. These methods are all ways of redistributing the space in which the original industrial heritage is located. In other words, from the perspective of public participation, these methods of industrial heritage protection and reuse can, to a certain extent, satisfy the public's demands for fair distribution of space. Therefore, the contradiction between public participation and elite awareness is resolved, and public awareness needs are emphasized, which can improve the social acceptance of the planning scheme.

Besides, according to interviews with residents, if the mining area of Pingdingshan were to be completely discontinued, this would have a significant impact on residents lives. Almost all respondents mentioned employment problems. Such concerns are not difficult to see, as more than half of them are engaged in coal-related occupations, and among the remaining respondents, many of their family members are also engaged in mining-related occupations (Figure 4). According to the survey data, in the context of industrial transformation and the decline of coal mining, many people choose to turn to new jobs (Figure 15), with tourism being the most popular choice. In addition, economic development problem was also a concern for residents of Pingdingshan (Figure 5). From the completion of Pingdingshan City to today, coal mining and related industries have been the main economic pillars of the city. The closure of the coal industry would directly affect the city's GDP, which is a major concern for residents. The European Commission Constitution pointed out that the protection of cultural heritage can promote economic and social progress. Some experts also believe that public participation in the development of cultural heritage can bring economic benefits, such as tourism [73]. Sad stated that public participation in industrial heritage protection can be obtained not only from the government and the coalition, but also from the private sector [16]. This would enhance the social cohesion of the planning project, ease the government's economic pressure, and promote the city's sustainable economic development. Working with a wide range of stakeholders is critical to laying a good foundation for sustainable planning and action for cultural heritage [74]. The public can be directly involved in planning through government and 
non-governmental organizations and academic institutions. Possible ways to protect and reuse industrial heritage sites include building a museum on the original site, transforming it into a landscape park to provide public recreation space for local residents, or undertaking comprehensive development combined with shopping and tourism. These strategies can bring new employment opportunities for residents. A successful example is Allgemeine Elektrizitätsgesellscha (AEG) in Berlin, Germany, which is one of the historic centers of Berlin's large industry [75]. From 1995 to 2010, the industrial zone experienced a major transformation process through the construction of industrial parks and the investment of new industries. So far, about 2400 new jobs have been created in Oberschöneweide [76].

\section{Conclusions}

\subsection{Brief Summary}

From the previous data analysis, it can be seen that the position of coal in Pingdingshan is very important. Pingdingshan is a city that is excited by coal mining. However, the planning for the protection and reuse of its industrial heritage is still at the blueprint stage. From the government level to the residents' attention to industrial heritage, the prevalence of related knowledge is not high. Despite this, because the industrial heritage of Pingdingshan is of great significance to the city and local residents, it is hoped that planning for the protection and reuse of the industrial heritage sites in Pingdingshan will eventually be taken seriously. On the other hand, the level of public participation in Pingdingshan is not high. In general analysis, it is at about stage 2: collaboration, which means that there is a certain degree of public participation but that the public's right to speak is not high. In other words, the demands of the residents are not heard by the government and relevant planning departments. In the literature review, this paper finds that schemes for industrial heritage protection and planning are mostly considered from the perspectives of the economy, the ecological environment, history, and culture. That is to say, the elite consciousness guides the planning and design, and public opinion is not among the main reference factors. This raises several questions: why do we need to ensure that planning and design for the protection and reuse of industrial heritage are in keeping with the public's demands? How should we establish the approach to industrial heritage protection and reuse from the perspective of public participation? This paper presents three research questions:

First of all, can residents' emotional appeals ("sense of belonging") help to protect and reuse industrial heritage? Through the analysis of the above data, it was shown that residents have deep feelings for the legacy of the industrial heritage period. These heritage sites could become the city's business cards and historical features of Pingdingshan, and thus a source of emotional sustenance of the residents' sense of belonging and locality. Therefore, the public's emotional appeals also promote the planning policy for industrial heritage protection, and residents, who are in direct contact with this heritage, can make useful suggestions: for example, which are the most emotionally meaningful equipment, workshops, etc., for them?

Next, what effect does the degree of public participation have on the planning of industrial heritage protection and reuse? The analysis in this paper finds that there are differences and contradictions between public appeals and elite consciousness in traditional planning. Because the planning project for Pingdingshan is mainly in top-down form, the elites are the leaders of this planning; the degree of public participation is not high, and the public has no right to speak. However, through data and case studies, it is found that although some plans lack public participation, they satisfy residents' demands, and such planning is strongly accepted by the masses. However, when a planning project does not listen to the opinions of the masses, it will lack certain social acceptance. For example, Pingdingshan government officials hope to convert the mining area into commercial and residential areas, and $14 \%$ of residents are opposed to this and are unwilling to consume the facilities offered. 
Finally, the study considered whether the protection and reuse of industrial heritage can solve social conflicts in terms of the public's demands. From the questionnaires and interviews, it appears that residents' main concern is about employment problems and issues with economic development after the suspension of production in the mining area. If these problems are not handled properly, they will cause social instability and other problems. An understanding of these public demands would make it possible to solve these social problems by devising and formulating ways to protect and reuse industrial heritage. This paper provides guidance for this case. For example, the transformation of the tourism complex in the Ruhr industrial area in Germany has not only brought new economic income to the local area, but also created many new positions for the local residents.

In general, the establishment of the protection and reuse of industrial heritage through the perspective of public participation can meet the different demands of the public, enhance social acceptance of planning projects, and at the same time, contribute to the resolution of social problems. The protection scope and methods of industrial heritage protection and reuse require public participation and guidance. In other words, whether it is reusing abandoned industrial regions to create liveable cities, or to retrofit industrial regions with green spaces, it needs to refer to the wishes of the public.

\subsection{Recommendations}

There is a need to strengthen knowledge, education and public awareness. According to the previous analysis, public participation is currently not high in Pingdingshan. Many people lack awareness of the concept of industrial heritage protection, and thus fail to appreciate the cultural value of industrial sites. Therefore, in terms of increasing public participation, the public must first be made aware that their demands can be met. This requires greater publicity and education from the outset, by cooperating with the planning department and modern media, and ensuring that citizens can participate in the entire process of industrial heritage protection and reuse, such as setting up regular seminars for relevant groups and supervising project implementation [77].

Moreover, multiple interest groups should be encouraged to work together. For the management of industrial heritage protection, the protection of industrial heritage can rely on various stakeholders, such as volunteers, charitable trusts, and private and commercial organizations to operate and manage the protection and reuse of industrial heritage under such a platform. Additional financial support is guaranteed to ensure the smooth implementation of the protection plan. Through the cultural sector, interested groups are brought together to stimulate the sense of protection of the heritage, and to promote it to the wider society through visual effects and graphical media [78]. Through policy support, a fair and friendly platform for exchange and consultation can be established so that stakeholders in the society can coordinate the interests of all parties under the leadership of the government and resolve conflicts between the public and the elite. In this way, social inequality is alleviated, social contradictions brought about by industrial heritage protection are avoided, and all parties benefit.

Strengthen cooperation with various education departments. In addition, considering the long-term development of multiple channels of citizen participation, industrial heritage protection can consider cooperation with local cultural and educational departments, such as local schools and libraries and research institutions, increase the intensity of curriculum training and education, and establish an expert consultation platform. It is also possible to transform industrial sites into public cultural buildings so that people can participate, visit, shop, study and engage in other activities to understand the value of industrial heritage and the relationship of citizens themselves [79]. This allows residents to give high-quality advice from the right perspective, and can also raise citizens' awareness of protection and stimulate their collective consciousness and local identity. Ultimately, it can serve as a form of social support through which the government can protect industrial heritage, respond to the call of government departments in a timely manner, and increase social acceptability. 
Author Contributions: Conceptualization, X.W. and L.Y.; methodology, X.W. and L.Y.; software, X.W. and H.F.; validation, X.W., L.Y. and J.W.; formal analysis, X.W.; investigation, X.W.; resources, L.Y.; data curation, X.W. and L.Y.; writing-original draft preparation, X.W.; writing-review and editing, L.Y. and J.W.; visualization, H.F.; supervision, L.Y. and J.W.; project administration, L.Y.; All authors have read and agreed to the published version of the manuscript.

Funding: This research received no external funding.

Institutional Review Board Statement: Not applicable.

Informed Consent Statement: Not applicable.

Data Availability Statement: The data presented in this study are available on request from the author.

Acknowledgments: All authors have consented to the acknowledgment.

Conflicts of Interest: The authors declare no conflict of interest.

\section{Appendix A}

Undergraduate\& Taught PGR Projects

\section{Cardiff School of Geography and Planning}

\section{Student Projects (Undergraduate \& Taught Masters)}

This form must be completed and submitted to Evelyn Osborne email: OsborneE1@cardiff.ac.uk / Tel Ext: 76131 / Room 2.54 Glamorgan Building).

In the case of dissertations it is the responsibility of the student to submit the form, duly signed by their supervisor, and secure ethical approval prior to any fieldwork commencing.

A copy of the signed form should be included by all students with their final dissertation.

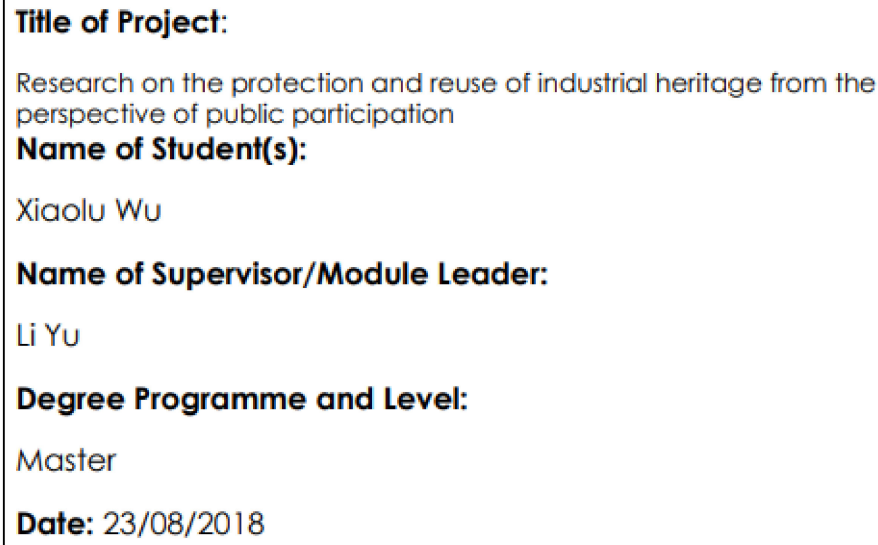

\begin{tabular}{|c|c|c|c|c|}
\hline \multicolumn{2}{|c|}{ Recruitment Procedures: } & Yes & No & N/A \\
\hline 1 & $\begin{array}{l}\text { Does your project include children under } 16 \text { years of } \\
\text { age? }\end{array}$ & $\checkmark$ & & \\
\hline 2 & Have you read the Child Protection Procedures below? & $\checkmark$ & & \\
\hline 3 & $\begin{array}{l}\text { Does your project include people with learning or } \\
\text { communication difficulties? }\end{array}$ & & $\sqrt{ }$ & \\
\hline 4 & Does your project include people in custody? & & $\checkmark$ & \\
\hline 5 & $\begin{array}{l}\text { Is your project likely to include people involved in illegal } \\
\text { activities? }\end{array}$ & $\checkmark$ & & \\
\hline
\end{tabular}


Undergraduate\& Taught PGR Projects

\begin{tabular}{|l|l|l|l|l|}
\hline 6 & $\begin{array}{l}\text { Does your project involve people belonging to a } \\
\text { vulnerable group, other than those listed above? }\end{array}$ & & $\checkmark$ & \\
\hline $\mathbf{7}$ & $\begin{array}{l}\text { Does your project include people who are, or are likely } \\
\text { to become your clients or clients of the department in } \\
\text { which you work? }\end{array}$ & & $\checkmark$ & \\
\hline $\mathbf{8}$ & $\begin{array}{l}\text { Does your project include people for whom English / } \\
\text { Welsh is not their first language? }\end{array}$ & $\checkmark$ & & \\
\hline $\mathbf{9}$ & Have you read the Data Protection Policy below? & $\checkmark$ & & \\
\hline $\mathbf{1 0}$ & Have you read the Health \& Safety Policy below? & $\checkmark$ & & \\
\hline
\end{tabular}

* Cardiff University's Child Protection Procedures:

https://www.cardiff.ac.Uk/ data/assets/pdf file/0009/995094/Safeguarding-PolicyOctober-2017.pdf

If you have answered 'yes' to any of the above questions please outline (in an attached ethics statement) how you intend to deal with the ethical issues involved

\begin{tabular}{|l|l|l|l|l|}
\hline \multicolumn{2}{|l|}{ Data Protection: } & Yes & No & N/A \\
\hline 11 & $\begin{array}{l}\text { Will you tell participants that their participation is } \\
\text { voluntary? }\end{array}$ & $\checkmark$ & & \\
\hline $\mathbf{1 2}$ & $\begin{array}{l}\text { Will you obtain written consent for participation? If } \\
\text { "No" please explain how you will be getting } \\
\text { informed consent. }\end{array}$ & $\checkmark$ & & \\
\hline $\mathbf{1 3}$ & $\begin{array}{l}\text { If the research is observational, will you ask } \\
\text { participants for their consent to being observed? }\end{array}$ & $\checkmark$ & & \\
\hline $\mathbf{1 4}$ & $\begin{array}{l}\text { Will you tell participants that they may withdraw } \\
\text { from the research at any time and for any reasons? }\end{array}$ & $\checkmark$ & & \\
\hline $\mathbf{1 5}$ & $\begin{array}{l}\text { Will you give potential participants a significant } \\
\text { period of time to consider participation? }\end{array}$ & $\checkmark$ & & \\
\hline
\end{tabular}

If you have answered 'no' to any of these questions please explain (in your ethics statement) the reasons for your decision and how you intend to deal with any ethical decisions involved

\section{Possible Harm to Participants:}

Yes 
Undergraduate\& Taught PGR Projects

\begin{tabular}{|c|l|l|l|l|}
\hline 16 & $\begin{array}{l}\text { Is there any realistic risk of any participants } \\
\text { experiencing either physical or psychological } \\
\text { distress or discomfort? }\end{array}$ & $\checkmark$ & \\
\hline 17 & $\begin{array}{l}\text { Is there any realistic risk of any participants } \\
\text { experiencing a detriment to their interests as a result } \\
\text { of participation? }\end{array}$ & $\checkmark$ & & \\
\hline
\end{tabular}

\begin{tabular}{|l|l|l|l|l|}
\hline \multicolumn{2}{|l|}{$R$ sesearch Governance: } & Yes & No & N/A \\
\hline 18 & $\begin{array}{l}\text { Does your study include the use of a drug? } \\
\text { You will need to contact Research Governance } \\
\text { before submission (resgov@cf.ac.uk) }\end{array}$ & $\checkmark$ & \\
\hline 19 & $\begin{array}{l}\text { Does the study involve the collection or use of } \\
\text { human tissue? } \\
\text { You will need to contact the Human Tissue Act } \\
\text { team before submission (hta@cf.ac.uk) }\end{array}$ & $\checkmark$ & \\
\hline
\end{tabular}

If there are any risks to the participants you must explain in your ethics statement how you intend to minimise these risks

\begin{tabular}{|l|l|l|l|l|}
\hline \multicolumn{2}{|l|}{ Data Protection: } & Yes & No & N/A \\
\hline 20 & $\begin{array}{l}\text { Will any non-anonymised and/or personalised data } \\
\text { be generated and/or stored? }\end{array}$ & & $\checkmark$ & \\
\hline 21 & $\begin{array}{l}\text { Will you have access to documents containing } \\
\text { sensitive' data about living individuals? } \\
\text { If "Yes" will you gain the consent of the individuals } \\
\text { concerned? }\end{array}$ & & $\checkmark$ & \\
\cline { 2 - 5 }
\end{tabular}

\section{Data protection Act Guidelines}

https://www.cardiff.ac.uk/public-information/policies-and-procedures/data-protection 
If there are any other potential ethical issues that you think the Committee should consider please explain them in an ethics statement. It is your obligation to bring to the attention of the Committee any ethical issues not covered on this form.

\begin{tabular}{|l|l|}
\hline Health and Safety: & Yes \\
\cline { 2 - 2 } $\begin{array}{l}\text { Does the research meet the requirements of the University's Health \& } \\
\text { Safety policies? }\end{array}$ & $\checkmark$ \\
https://www.cardiff.ac.uk/ data/assets/pdf file/0008/89405/SHWE-Policy- & \\
\hline Statement-English.pdf & \\
\cline { 2 - 2 } $\begin{array}{l}\text { Does the study involve the collection or use of human tissue (including, } \\
\text { but not limited to, blood, saliva and bodily waste fluids)? }\end{array}$ & \\
$\begin{array}{l}\text { If yes, a copy of the submitted application form and any supporting } \\
\text { documentation must be emailed to the Human Tissue Act Compliance } \\
\text { Team (HTA@cf.ac.uk). A decision will only be made once these } \\
\text { documents have been received. }\end{array}$ & \\
\end{tabular}

What are the main objectives of this research?

Obtain residents' attitudes and suggestions on the location of the case

Who are the research participants?

Residents of Pingdingshan,

People working in Pingmei Shenma Group,

People working in Pingdingshan City Government Department 


What methodologies will you be using?
Questionnaire
Interview
Qualitative research
Collection of government documents

Any changes to the nature of the project that result in the project being significantly different to that originally approved by the committee must be communicated to the Ethics Committee immediately.

Undergraduate\& Taught PGR Projects

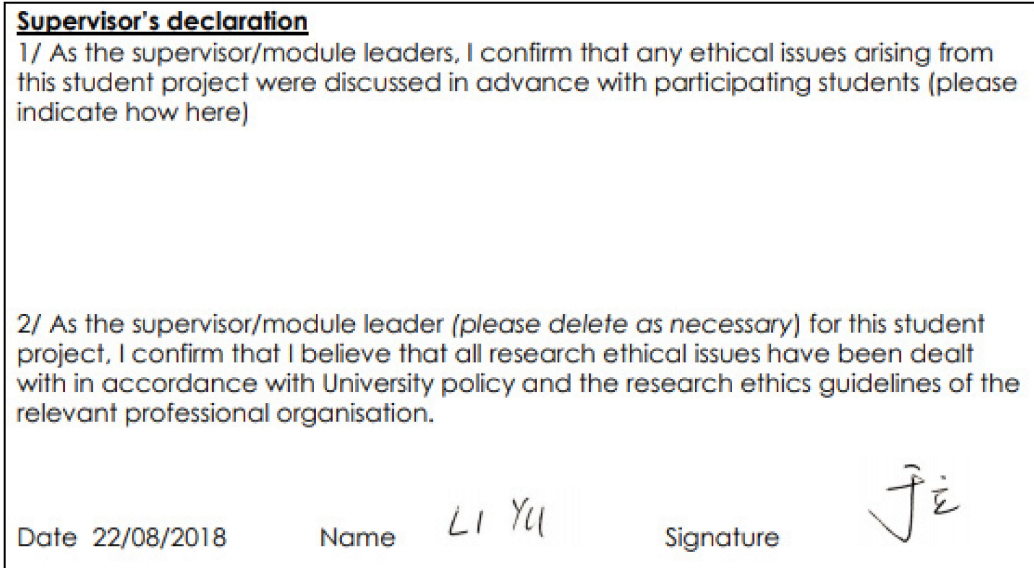

If any of the shaded boxes have been ticked the supervisor/module leader must explain below how the potential ethical issue will be handled:

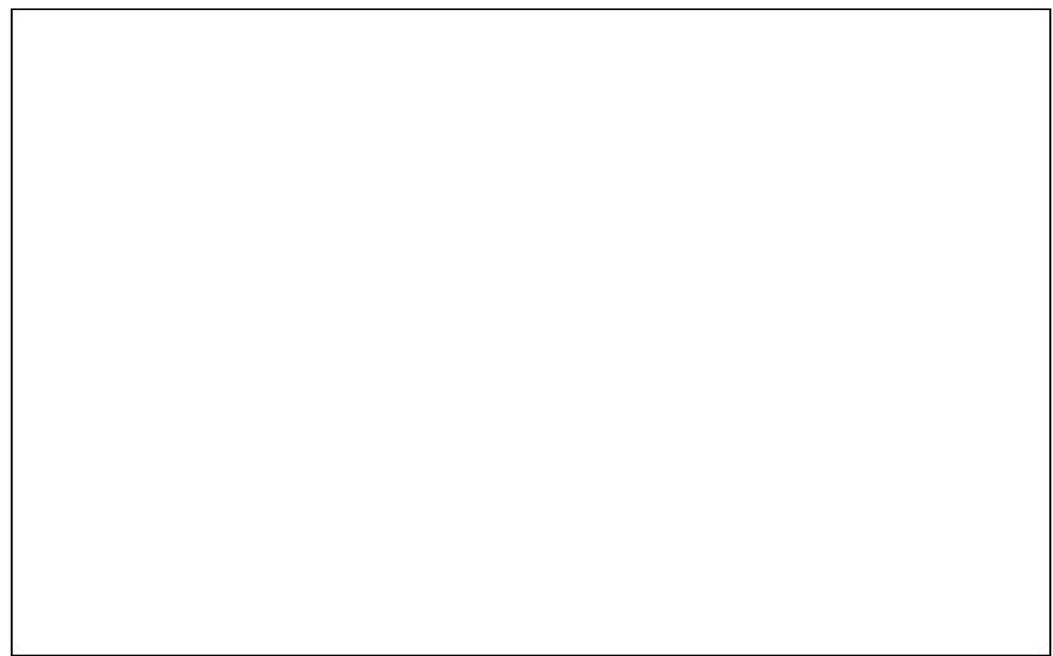




\section{Appendix B}

Questionnaire

Research Questionnaire of Industrial Heritage Protection and Reuse

Age ( ) Education level ( ) Occupation ( )

1. What is the most impressive thing about Pingdingshan in your heart?

2. Is the existence of coal mine important for your life? A. Very important B. General C. Less important

3. If the mine is completely shut down, and the building and equipment (office building, mining machine, etc.) are dismantled, do you feel regret for this? [Yes, No] Why?

4. Have you heard of the protection and reuse of old mines and equipment? No Yes [multiple choice] A. Friends and family B. TV broadcasting C. Internet D. Newspapers and magazines

5. Do you think old mines, equipment, etc. should be protected? No Yes [multiple choice] A. Have feelings B. Have cultural protection value C. Have economic value D. Other

6. If the coal mine is shut down, what do you hope to transform into here: [multiple choice] A. Park B. Shopping mall C. Restaurant D. Playground E. Museum F. Warehouse G. Residential H. Mine Industrial Heritage Park I. Other

7. You choose the industrial heritage (abandoned office building, mining machine, etc.) that you are interested in. The experience basis is: [multiple choice] A. Increase your knowledge and cultivate your sentiments. B. Nostalgic feelings, artistic enjoyment C. Leisure and entertainment, killing time D. Interactivity, strong participation F. Other

8. If you want to engage in other industries after the coal mine is shut down? If so, please choose: A. Chemical industry production industry B. Textile production industry C. New energy industry (e.g., solar power generation, etc.) D. Tourism and related industries E. Service industry F. Others

9. If the coal mine plant is later transformed into a tourist scenic spot or a commercial district, will you consider going to consumption? A. Willing B. Unwilling

10. What do you think are the main environmental problems caused by coal mining companies? A. Deterioration of the air environment B. Water pollution C. Soil pollution D. Ground subsidence E. Others

11. What impact does the mine have on your life after it has been discontinued?

\section{References}

1. Ma, Y. Thoughts on the Protection and Reuse of China's Industrial Heritage under the Background of Urban Renewal-Taking the Industrial Heritage of Luxi West Fujian as an Example. Henan Educ. High. Educ. Ed. 2018, 5, 28-30.

2. Zhang, X.; Zha, C. Hefei Industrial Heritage Protection and Its Reuse. J. Anhui Univ. Technol. Soc. Sci. Ed. 2011, 1, 186-188.

3. TICCIH. The Nizhny Tagil Charter for the Industrial Heritage. In Proceedings of the TICCIH XII International Congress, Moscow, Russia, 17 July 2003.

4. Clark, J. Adaptive Reuse of Industrial Heritage: Opportunities \& Challenges. Herit. Counc. Vic. 2013, 1-7. Available online: https://heritagecouncil.vic.gov.au/wp-content/uploads/2014/08/HV_IPAWsinglepgs.pdf (accessed on 16 November 2021).

5. Somoza-Medina, X.; Monteserín-Abella, O. The Sustainability of Industrial Heritage Tourism Far from the Axes of Economic Development in Europe: Two Case Studies. Sustainability 2021, 13, 1077. [CrossRef]

6. ICOMOS. In ICOMOS General Assembly Entitled Patrimonio y Conservación. Arqueología. 1999. Available online: http: //www.icomos.org/australia/burra.html (accessed on 15 August 2017).

7. Ashworth, G. Preservation, Conservation and Heritage: Approaches to the Past in the Present through the Built Environment. Asian Anthropol. 2011, 10, 1-18. [CrossRef]

8. Fahmi, W.; Sutton, K. Greater Cairo's Housing Crisis: Contested Spaces from Inner City Areas to New Communities. Cities 2008, 25, 277-297. [CrossRef]

9. Loures, L. Industrial Heritage: The past in the future of the city. Ind. Landsc. 2008, 4, 687-696.

10. Jansen-Verbeke, M. Cultural tourism in the 21st century. World Leis. Recreat. 1996, 1, 6-11. [CrossRef]

11. Swensen, G. Integration of historic fabric in new urban development-A Norwegian case-study. Landsc. Urban Plan. 2012, 107, 380-388. [CrossRef]

12. Laurian, L.; Shaw, M.M. Evaluation of public participation: The practices of certified planners. J. Plan. Educ. Res. 2009, 28, 293-309. [CrossRef] 
13. Moore, N.; Whelan, Y. Heritage, Memory and the Politics of Identity: New Perspectives on the Cultural Landscape; Ashgate: Aldershot, $\mathrm{UK}, 2007$.

14. Xing, H. A Probe into the Value and Protection of Industrial Heritage. J. Northeast. Univ. Soc. Sci. Ed. 2007, 1, 16-19.

15. Llurdts, J.C. El turismo industrial y la estCtica de 10s paisages en declive. Estud. Tur. 1994, 21, 91-107.

16. Copić, S.; Dordević, J.; Lukic, T.; Stojanović, V.; Tumarić, A. Transformation of Industrial Heritage-An Example of Tourism Industry Development in the Ruhr Area (Germany). Geogr. Pannonica. 2014, 18, 43-50. [CrossRef]

17. Del Pozo, P.B.; González, P.A. Industrial heritage and place identity in Spain: From monuments to landscapes. Geogr. Rev. 2012, 102, 446-464. [CrossRef]

18. Wang, J.; Jiang, N. Conservation and adaptive-reuse of historical industrial building in China in the post-industrial era. Front. Archit. Civ. Eng. China 2007, 1, 474-480. [CrossRef]

19. Ashworth, G.; Graham, B.; Tunbridge, J. Pluralising Pasts: Heritage, Identity and Place in Multicultural Societies; Pluto Press: London, UK, 2007.

20. Cole, D. Exploring the sustainability of mining heritage tourism. J. Sustain. Tour. 2004, 12, 480-494. [CrossRef]

21. Edwards, J.A.; Llurdés i Coit, J.C. Mines and quarries: Industrial heritage tourism. Ann. Tour. Res. 1996, 23, 341-363. [CrossRef]

22. Jansen-Verbeke, M. Industrial heritage: A nexus for sustainable tourism development. Tour. Geogr. 1999, 1, 70-85. [CrossRef]

23. Cai, D. Public Participation and Its Development in China. 2012. Available online: http://www.chinareform.org.cn/gov/ governance/practice/201204/t20120415_139364_1.htm (accessed on 14 April 2018).

24. China Association for Science and Technology (CAST). China Industrial Heritage Protection List (First Batch) Officially Released. 2018. Available online: http:/ /www.cast.org.cn/n200685/c57896756/content.html (accessed on 31 January 2018).

25. Chan, B. The modern decline and revival of participatory democracy. Chin. Acad. Soc. Sci. 2009, 18-20. [CrossRef]

26. Wang, X. Institutional Practice of Public Participation in Administrative Process. China Leg. Publ. House 2008, 10, 2.

27. Jia, X. Chinese Citizen Participation-Cases and Models. Soc. Sci. Lit. Publ. House 2008, 10, 1.

28. Pingdingshan Municipal People's Government. Comprehensive Renovation Planning for the Northern Mining Area of Pingdingshan City; Pingdingshan Municipal People's Government: Pingdingshan, China, 2015.

29. Landorf, C. A framework for sustainable heritage management: A study of UK industrial heritage sites. Int. J. Herit. Stud. 2009, 15, 494-510. [CrossRef]

30. Spennemann, D.H.R. Gauging Community Values in Historic Preservation. CRM J. Herit. Steward. 2006, 3, 6-20.

31. Zhong, X.; Leung, H.H. Exploring participatory microregeneration as sustainable renewal of built heritage community: Two case studies in Shanghai. Sustainability 2019, 11, 1617. [CrossRef]

32. Arnstein, S. A Ladder of Citizen Participation. J. Am. Inst. Plan. 1969, 35, 216-224. [CrossRef]

33. Connor, M. A New Ladder of Citizen Participation. Natl. Civ. Rev. 1988, 77, 249-257. [CrossRef]

34. Tosun, C. Towards a typology of community participation in the tourism development process. Anatolia 1999, 10, 113-134. [CrossRef]

35. Tosun, C. Expected nature of community participation in tourism development. Tour. Manag. 2006, 27, 493-504. [CrossRef]

36. Zhang, Y.; Cole, S.T.; Chancellor, C.H. Residents' preferences for involvement in tourism development and influences from individual profiles. Tour. Plan. Dev. 2013, 10, 267-284. [CrossRef]

37. Rasoolimanesh, S.M.; Jaafar, M.; Ahmad, A.G.; Barghi, R. Community participation in World Heritage Site conservation and tourism development. Tour. Manag. 2017, 58, 142-153. [CrossRef]

38. SenStadtUm (Senatsverwaltung für Stadtentwicklung und Umwelt Berlin). Handbuch der Partizipation; Kulturbuch-Verlag GmbH: Berlin/Heidelberg, Germany, 2011.

39. Henan Survey Organization National Bureau of Statistics Information Network. 2017. Available online: http://www.hadc.gov. $\mathrm{cn} /$ dczdcms/html/32/599/2017-1-9/312.html (accessed on 25 August 2018).

40. Wengraf, T. Qualitative Research Interviewing: Biographic Narrative and Semi-Structured Methods; Sage: Hemet, CA, USA, 2001.

41. Silverman, D. Doing Qualitative Research, 4th ed.; Sage Publications Ltd.: London, UK, 2013.

42. Bell, J. Doing Your Research Project; McGraw-Hill Open University Press: Berkshire, UK, 2010.

43. China Coal Resources Network. 2017. Available online: https://www.chyxx.com/industry/201707/541654.html (accessed on 28 August 2018).

44. Pingdingshan Urban and Rural Planning Bureau. Pingdingshan Urban Green Space System Plan; Henan Urban Planning and Design Research Institute Co., Ltd.: Zhengzhou, China, 2012.

45. Özgüner, H.; Kendle, A.D. Public attitudes towards naturalistic versus designed landscapes in the city of Sheffield (UK). Landsc. Urban Plan. 2006, 74, 139-1573. [CrossRef]

46. Baker, H.; Moncaster, A.; Al-Tabbaa, A. Decision-making for the demolition or adaptation of buildings. Proc. Inst. Civ. Eng. Forensic Eng. 2017, 170, 144-156. [CrossRef]

47. Pingdingshan City Cultural Relics Bureau. The 13th Five-Year Plan for the Development of Pingdingshan Cultural Relics Museum; Pingdingshan City Cultural Relics Bureau: Pingdingshan, China, 2015.

48. The China Association for Science and Technology Innovation Strategy Research Institute and the China Urban Planning Society. The list of China's industrial heritage protection list (First batch). Mod. Sci. 2018, 1, 79-85.

49. The China Association for Science and Technology Innovation Strategy Research Institute and the China Urban Planning Society. The list of China's industrial heritage protection list (Second batch). Mod. Sci. 2019, 5, 84-91. 
50. Fiorino, D. Environmental Policy and the Participation Gap. In Democracy and the Environment: Problems and Prospects; Edward Elgar Publishing: Gloucestershire, UK, 1996; pp. 194-212.

51. Britton, M. An Evaluation of Public Involvement in Reclamation Decision Making at Three Metal Mines in British Columbia. Master's Thesis, The University of British Columbia, Vancouver, BC, Canada, 1998.

52. Pingdingshan Government Website. What Are Your Good Comments and Suggestions on the Design of the "Planning and Ecological Recreation Area of the Northern Mountain of Pingdingshan City?". 2018. Available online: http://www.pds.gov.cn/ contents/1035/52831.html (accessed on 28 August 2018).

53. Aas, C.; Ladkin, A.; Fletcher, J. Stakeholder collaboration and heritage management. Ann. Tour. Res. 2005, 32, 28-48. [CrossRef]

54. Hung, K.; Sirakaya-Turk, E.; Ingram, L.J. Testing the efficacy of an integrative model for community participation. J. Travel Res. 2011, 50, 276-288. [CrossRef]

55. Tosun, C. Limits to community participation in the tourism development process in developing countries. Tour. Manag. 2000, 21, 613-633. [CrossRef]

56. Proshansky, H.M. The city and self identity. Environ. Behav. 1978, 10, 147-169. [CrossRef]

57. Proshansky, H.M.; Fabian, A.K.; Kaminoff, R. Place identity: Physical world socialization of the self. J. Environ. Psychol. 1983, 3, 57-83. [CrossRef]

58. Haywantee, R.; Liam, S.; Betty, W. Relationships between place attachment, place satisfaction and pro-environmental behaviour in an Australian national park. J. Sustain. Tour. 2012, 21, 1-24.

59. Williams, D.; Vaske, J. The measurement of place attachment: Validity and generalizability of a psychometric approach. For. Sci. 2003, 49, 830-840.

60. Williams, D.R.; Patterson, M.E.; Roggenbuck, J.W.; Watson, A.E. Beyond the commodity metaphor: Examining emotional and symbolic attachment to place. Leis. Sci. 1992, 14, 29-46. [CrossRef]

61. Kyle, G.T.; Graefe, A.R.; Manning, R. Testing the dimensionality of place attachment in recreational settings. Environ. Behav. 2005, 37, 153-177. [CrossRef]

62. Kyle, G.T.; Chick, G. The social construction of a sense of place. Leis. Sci. 2007, 29, 209-226. [CrossRef]

63. Lewicka, M. Place attachment. How far have we come in the last 40 years? J. Environ. Psychol. 2011, 31, 207-230. [CrossRef]

64. Trentelman, C. Place attachment and community attachment: A primer grounded in the lived experience of a community sociologist. Soc. Nat. Resour. 2009, 22, 191-210. [CrossRef]

65. Cho, M.; Shin, S. Conservation or economization? Industrial heritage conservation in Incheon, Korea. Habitat Int. 2014, 41, 69-76. [CrossRef]

66. Oloonabadi, S.S.A.; Ardakani, M.K. Collective memory as an efficient agent in sustainable urban conservation. Procedia Eng. 2011, 21, 985-988. [CrossRef]

67. Ahmadi, O.S.; Keramati, A.M. The Role of Collective Memory in Linking the Old Parts of the City: A Case of Ardakan. In Proceedings of the Heritage 2011 Conference, The Second International Conference on Conservation of Architecture, Urban Areas and Landscape, Amman, Jordan; The Center for the Study of Architecture in Arab Region: Amman, Jordan, 2011; pp. 173-189.

68. Davis, P.; Huang, H.-Y.; Liu, W.-C. Heritage, local communities and the safeguarding of "Spirit of Place" in Taiwan. Mus. Soc. 2010, 8, 80-89.

69. David, S. Place Attachment and Phenomenology: The Synergistic Dynamism of Place. In Place Attachment: Advances in Theory, Methods, and Applications; Routledge/Francis \& Taylor: New York, NY, USA, 2014; pp. 11-22.

70. Yang, K. Public administrators' trust in citizens: A missing link in citizen involvement efforts. Public Adm. Rev. 2005, 65, 262-275. [CrossRef]

71. Marzuki, A.; Hay, I.; James, J. Public participation shortcomings in tourism planning: The case of the Langkawi Islands, Malaysia J. Sustain. 2012, 20, 585-602. [CrossRef]

72. Faga, B. Designing Public Consensus-The Civic Theater of Community Participation for Architects, Landscape Architects, Planners, and Urban Designers; John Wiley \& Sons: Hoboken, NJ, USA, 2006.

73. Statute of the Council of Europe. 1949. Available online: http://www.worldlii.org/int/other/COETS/1949/1.html (accessed on 21 December 2021)

74. Interreg Europe. Citizen Engagement in the Protection of Cultural Heritage (August); Interreg Europe Policy Learning Platform on Environment and Resource Efficiency: Paris, France, 2017.

75. Landesdenkmalamt Berlin. Denkmale in Berlin: Treptow-Köpenick, Ortsteile Nieder-Und Oberschöneweide; Michael Imhof Verlag: Petersberg, Russia, 2003.

76. Oevermann, H.; Degenkolb, J.; Dießler, A.; Karge, S.; Peltz, U.; Karge, S. Participation in the reuse of industrial heritage sites: The case of Oberschöneweide, Berlin. Int. J. Herit. Stud. 2016, 22, 43-58. [CrossRef]

77. Protection and Reuse of Industrial Heritage: Dilemmas, Problems; ICOMOS Slovenia: Ljubljana, Slovenia, 2015.

78. Cizler, J. Urban regeneration effects on industrial heritage and local community-Case study: Leeds, UK. Sociol. Prost. 2012, 56, 223-236. [CrossRef]

79. APPGs; All-Party Parliamentary Group on Industrial Heritage. Reporty on the Challenges Facing the Industrial Heritage Sector; APPG on Industrial Heritage: London, UK, 2018; p. 47. 